\title{
How to Operationalize Gender Issues in Country Work
}




\section{INTERNATIONAL MONETARY FUND}

June 2018

\section{HOW TO OPERATIONALIZE GENDER ISSUES IN} COUNTRY WORK

IMF staff regularly produces papers proposing new IMF policies, exploring options for reform, or reviewing existing IMF policies and operations. The Report prepared by IMF staff and completed on June 1, 2018, has been released.

The staff report was issued to the Executive Board for information. The report was prepared by IMF staff. The views expressed in this paper are those of the IMF staff and do not necessarily represent the views of the IMF's Executive Board.

The IMF's transparency policy allows for the deletion of market-sensitive information and premature disclosure of the authorities' policy intentions in published staff reports and other documents.

Electronic copies of IMF Policy Papers

are available to the public from

http://www.imf.org/external/pp/ppindex.aspx

\section{International Monetary Fund Washington, D.C.}




\section{INTERNATIONAL MONETARY FUND}

\section{HOW TO OPERATIONALIZE GENDER ISSUES IN COUNTRY}

WORK

\section{EXECUTIVE SUMMARY}

Reducing gender gaps can have important economic benefits. Gender gaps remain significant on a global scale, both with respect to opportunities and outcomes. For example, gender-based legal restrictions in many parts of the world, as well as barriers in access to education, healthcare, and financial services, prevent women from fully participating in the economy. In turn, labor force participation rates are lower among women than men. Gender equality can play an important role in promoting economic stability by boosting economic productivity and growth, enhancing economic resilience, and reducing income inequality.

The Fund has begun operationalizing gender issues in its work. Staff has contributed to the economic literature through country-level and cross-country analytical studies, confirming the macro-criticality of gender issues in a broad set of circumstances. Gender issues are also increasingly becoming an integral part of capacity development though technical assistance and training. And in country work, two waves of gender pilots have been completed-encompassing both surveillance and Fund-supported programs and covering all regions of the world and all levels of income-and a third wave is under way.

\section{Coverage of gender issues in staff reports should be selective and calibrated to} the degree of macroeconomic significance. All teams should consider whether gender issues are relevant, taking into account also the authorities' priorities, but with no presumption that gender issues will be covered everywhere or every year and with in-depth coverage anticipated in only a limited number of cases any year. Staff should point to macroeconomic significance where it exists, with analysis focused on aspects with economic implications and specific policy advice limited to areas where there is Fund expertise. Where relevant, country teams should leverage external expertise.

This note provides an overview of good practices and resources available to staff. The note is consistent with the 2015 Guidance Note for Surveillance Under Article IV Consultations and draws also on the 2013 Guidance Note on Jobs and Growth Issues in Surveillance and Program Work. It provides examples of good practice with respect to coverage of gender issues in country reports and lays out the resources available to country teams, both with respect to existing analytical work as well as the availability of data and tools. 
Approved By Sanjaya Panth
Prepared by an interdepartmental team led by Lone Christiansen and comprising Anna Bordon, Mai Farid, Lisa Kolovich, Anna Ter- Martirosyan (all SPR), and Monique Newiak (AFR); under the supervision of Sanjaya Panth (SPR) and Daria Zakharova (SPR chair of the Gender Advisory Group), and under the guidance of Kalpana Kochhar and Catherine Pattillo (both chairs of the Gender Advisory Group). Jelle Barkema (SPR) provided excellent research assistance.

\section{CONTENTS}

INTRODUCTION

MACRO-CRITICALITY OF GENDER ISSUES

A. Existing Literature

B. Gender Analysis at the Fund $\underline{8}$

COVERAGE OF GENDER ISSUES IN COUNTRY PAPERS $\underline{9}$

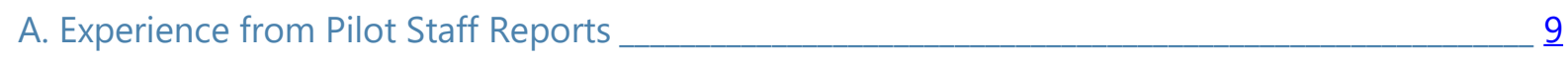

B. Covering Gender Issues in Staff Reports ____ 15

A. Internal Resources $\underline{19}$

B. External Resources $\underline{23}$

References

\section{BOXES}

1. Gender Budgeting

2. Examples of Good Practice when Covering Gender Issues in Country Reports 11

3. Leveraging Cross-Country Work on Gender in Bilateral Surveillance 14

4. Example of Gender Indicators in Country Reports $\underline{18}$

5. Selected Data Sources $\underline{21}$

6. A Dynamic Stochastic General Equilibrium Approach to Gender Inequality $\underline{24}$

\section{FIGURES}

1. Gender Pilots $\underline{3}$

2. Establishing Macro-Criticality $\underline{6}$

\section{TABLES}

1. First- and Second-Wave Pilots $\underline{26}$

2. Third-Wave Pilots $\underline{36}$ 


\section{INTRODUCTION}

1. Promoting global economic growth and stability requires an understanding of the underlying macro-critical drivers, including the role of gender equality. Women's participation in the labor market increases the size and talent pool of the labor force, helping to boost labor productivity and output. Women's economic empowerment-including through higher levels of school enrollment, equal rights, greater safety, and financial inclusion-can also help enhance economic resilience and reduce income inequality, thus supporting economic stability and sustainable growth. Greater gender equality is therefore integral to delivering on the IMF's mandate of promoting economic stability.

2. Gender issues have increasingly featured in the Fund's work program. In 2013, staff produced a Board paper on Jobs and Growth: Analytical and Operational Considerations for the Fund (IMF, 2013a) and an accompanying Guidance Note on Jobs and Growth Issues in Surveillance and Program Work (IMF, 2013b). The board paper noted the need for the Fund's work on issues related to jobs and growth-including gender inequality — to be consistent with its mandate and areas of expertise. In this context, the guidance note discussed how these issues should be covered in surveillance and program work. In 2015, the Article IV Surveillance guidance note was updated to cover emerging issues and operationalization of gender issues was included in the Board work program.

3. The Fund subsequently began operationalizing gender issues in its country work. In 2015 , the country pilot initiative was begun to accumulate knowledge and experience in operationalizing these issues. This allowed teams to innovate and test ideas on how to effectively integrate emerging issues (such as gender) into bilateral surveillance, tailoring staff advice to country-specific needs and determining how the Fund can best add value for the membership in this area. Country pilots were selected using two criteria: (i) macro-criticality ${ }^{1}$ and (ii) whether the issue is high on the authorities' policy agenda to increase initial policy traction.

\section{Two waves of pilots have now added} value in surveillance and a third is under way. Since 2015, 27 gender pilots have been completed as part of the first two waves, covering countries across five regions (Figure 1, Tables 1 and 2). Pilots included surveillance cases as well as Fund-supported programs, including with structural reform commitments to mitigate gender inequality. In several cases, Fund advice has gained traction with the authorities. Overall, the pilot initiative has added value in surveillance by making a strong case for

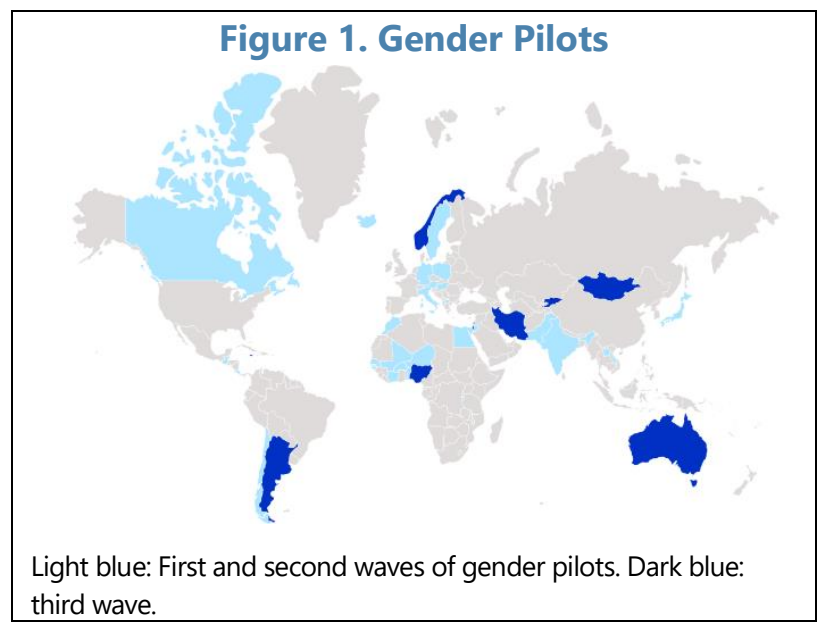

\footnotetext{
${ }^{1}$ An issue is macro-critical if it affects, or has the potential to affect, domestic or external stability (IMF, 2015a).
} 
macro-criticality of women's economic empowerment in the countries covered and highlighting the gender-differentiated impact of fiscal and labor market policies.

\section{The ongoing work to operationalize gender issues has benefitted from a dedicated} support network within the Fund and collaboration with external partners. Internally, the dedicated Gender Advisory Group ${ }^{2}$ has supported peer learning and sharing of knowledge, tools, and data. The Advisory Group has also facilitated external collaboration that took several forms. For example, in the context of an existing eight-year strategic partnership, which started in 2012, the Department of International Development (DFID) has provided funding for a regional gender-budgeting study, peer-learning events, and the development of models and analytical tools to assess interactions of gender equality with economic growth and income inequality.

Collaboration with the World Bank has included joint workshops, seminars, and knowledge sharing. UN Women has organized conferences and a high-level panel on women's economic empowerment with IMF participation and has jointly worked with the IMF to hold peer learning events. Other events include the Managing Director's participation in the World Assembly of Women. In addition, several pilot country teams have been engaged in country-level collaboration with external partners. Technical assistance is being broadened, seeking to incorporate aspects of gender budgeting, where relevant. The Fund has also engaged in assessing the availability of gender-disaggregated data on access to financial services. Overall, this has helped the Fund deliver high-quality advice, while keeping resource costs manageable.

\section{The analysis from the pilot experience can be incorporated into broader country work}

where relevant. The gender pilot initiative has helped accumulate much knowledge and internal expertise, which will be available for other country teams to incorporate in a selective and cost-effective manner. Going forward, coverage of macro-critical issues should be prioritized based on country circumstances, considering also the authorities' priorities (IMF, 2014). Teams should cover gender issues selectively where they are deemed macro-critical or when requested by the authorities. ${ }^{3}$ Where gender issues are not considered macro-critical, coverage is not expected. As such, there is no expectation that an in-depth coverage of gender issues is included in reports every year and for every country. Country teams should continue to focus on the issues and themes that are deemed most relevant for economic growth and stability. In addition, staff may find strong traction from gender-related recommendations where this issue is high on the authorities' policy agenda. Also, analyses can draw on existing work by key external partners (e.g., the World Bank) to reduce resource costs and avoid duplication. In cases where an in-depth study has been conducted by staff, country teams are expected to follow subsequent developments and the authorities' progress in implementing staff's recommendations, though updates in country reports are not required on a regular basis.

\footnotetext{
2 The Gender Advisory Group was formed in 2015 to provide analytical and operational support to pilot country teams, build and share knowledge and expertise on gender issues, and facilitate external collaboration. It is jointly led by Fiscal Affairs Department (FAD), the Human Resource Department (HRD), and the Strategy, Policy and Review Department (SPR), with representatives from area and functional departments.

${ }^{3}$ The analysis can be reported in a section of the staff report, a Box, an Annex, or a Selected Issues Paper. Staff reports should include the main recommendations and a summary of the discussion with the authorities.
} 
7. This how-to note does not substitute for, or supersede, any existing formal guidance notes and aims to provide operational support to country teams. The note updates the state of knowledge on gender issues since the issuance of the 2013 Guidance Note on Jobs and Growth Issues in Surveillance and Program Work (IMF, 2013b) and is consistent with the 2015 Guidance Note for Surveillance under Article IV Consultations (IMF, 2015a). While gender equality relates to the inclusion of both women and men, most references in this note relate to women's economic empowerment given the greater global prevalence of female than male under-inclusion. Section II outlines the macro-criticality of gender issues. Section III discusses how gender issues have been covered in country reports and lays out best practices for coverage of gender issues in staff reports. Finally, Section IV provides an overview of resources available to country teams, including in terms of toolkits, data, and analytical cross-country work and models that can be adopted into bilateral surveillance. While mostly discussing surveillance cases, this note is also relevant for Fund-supported programs and highlights coverage in recent program country reports.

\section{MACRO-CRITICALITY OF GENDER ISSUES}

8. Gender inequality is a multifaceted concept, covering both inequality in outcomes and in opportunities. For example, gender gaps in outcomes (e.g., gaps in labor force participation rates, wages, and representation on company boards and in senior management) often result from inequality in opportunities (e.g., gaps in access to financial services, education, healthcare, and basic infrastructure). Some of the underlying barriers to gender equality also include legal barriers, distortions from tax or spending polities, leave options, and insufficient childcare options. Overall, the extent and nature of the macro-criticality of gender issues are therefore expected to vary significantly across countries.

9. While important progress has been made in reducing gender inequality worldwide, significant gender gaps remain. Globally, there have been sizeable advances towards eliminating gender inequities as manifested in rising female labor force participation and literacy rates. Gender gaps in education have also been shrinking worldwide, and financial access has widened to more women around the world. However, despite these notable advances, gender disparities persist across all regions and income levels. Global female labor force participation rates remain low at about 50 percent (ages 15+), compared to 76 percent for men, (with levels and trends varying across regions), and women still trail men when it comes to literacy in several parts of the world (South Asia, East and North Africa, and sub-Saharan Africa). Maternal death and adolescent fertility rates also remain high in some countries, in particular, in sub-Saharan Africa. The World Bank's Women, Business and the Law data point to at least one legal restriction for women in close to 90 percent of the reporting economies (World Bank, 2015).

10. Gender equality is integral to promoting economic stability and growth. Gender issues are often of macro-critical importance, as women's economic empowerment is important for growth both through the direct impact of the size of the labor force on output and through the impact on productivity (Cuberes and Teignier, 2016) (Figure 2). For example, diversity and education can foster new ideas and thereby enhance productivity (Loko and Diouf, 2009). Greater gender equality in the 
labor market and education has also been linked to greater export diversification in developing and low-income economies, and thus to greater economic resilience (Kazandjian and others, 2016). In contrast, gender inequality has been shown to be associated with income inequality, which in turn can undermine sustainability of growth (Gonzales and others, 2015a; Ostry and others, 2014).

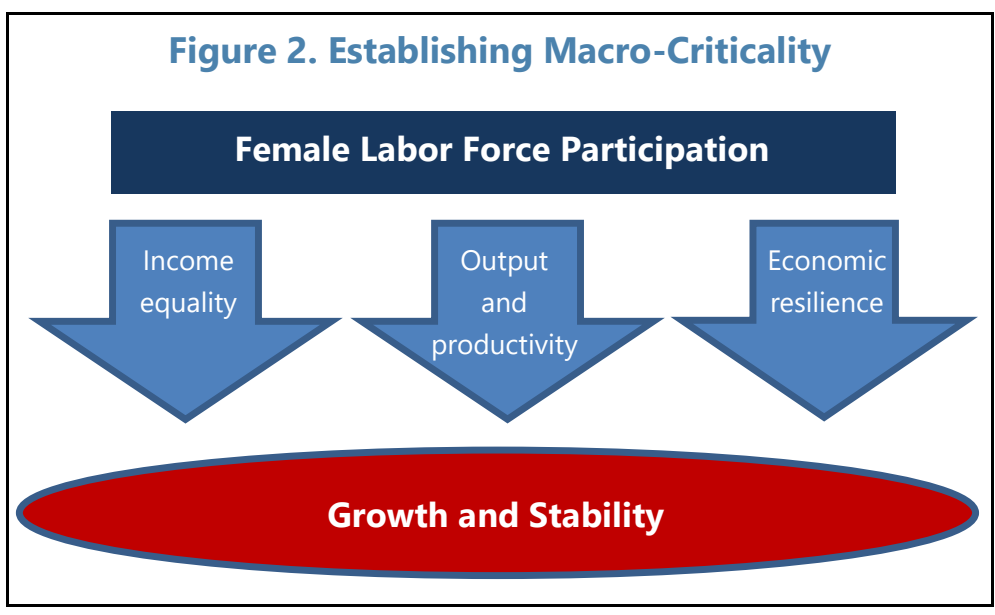

11. Economic policy levers can be used to reduce gender inequality. In fact, policies matter for women's employment decisions even after accounting for personal preferences toward working (Christiansen and others, 2016a). That said, needs often vary across income levels. In low-income and developing economies, policies often need to focus on investment in education, health, and infrastructure as well as on increasing financial inclusion. In advanced economies, policies more often need to focus on investing in childcare and reducing tax disincentives for secondary earners. Overall, gender budgeting can contribute to reaching these objectives (Box 1). Virtually all countries can do better by removing legal barriers to women's economic empowerment. In addition, consideration should be given to how various policies recommended by staff may interact and have potential differential gender implications.

\section{A. Existing Literature}

\section{A large literature has studied the macroeconomic impact of women's economic} empowerment. This literature has highlighted several dimensions in which gender inequality has macroeconomic and development-related implications (Elborgh-Woytek and others, 2013). For example, positive associations have been identified between gender equality on the one hand and per-capita GDP, the level of competitiveness, and human development indicators on the other hand (World Economic Forum, 2014; Duflo, 2012). And while priorities differ, more gender equality has been associated with better macroeconomic outcomes at all levels of development (Cuberes and Teignier, 2016). In addition, lower gender gaps in education and higher female labor force participation have been associated with higher diversification of output and export products (Kazandjian and others, 2016), supporting economic resilience in developing economies. Looking at the other side of the coin, gender gaps in economic participation tend to restrict the talent pool in the labor market and can thus yield a less efficient allocation of resources, losses in total factor productivity, and lower output growth (Cuberes and Teignier, 2016; Esteve-Volart, 2004). ${ }^{4}$

\footnotetext{
${ }^{4}$ For example, in a cross-country study, Klasen (1999) shows that 0.4 to 0.9 percentage point of the difference in growth rates between East Asia, sub-Saharan Africa, South Asia, and the Middle East can be explained by differences in gender gaps in education.
} 


\section{Box 1. Gender Budgeting}

What is gender budgeting? Government budgets and fiscal measures may have differential impact on women and men. Gender budgeting considers how government programs and policies can promote women's economic development and gender equality. It considers how these ideas can be incorporated into laws, regulations, and practices that govern the budget. After assessing the specific needs, fiscal authorities can use gender budgeting to set key goals, allocate funds correspondingly, and monitor and evaluate achievements.

\section{Gender budgeting spans all income levels but with the specific focus depending on the diverse set of} challenges. Gender budgeting has now been applied in more than 80 countries.

- In advanced economies, where gender gaps in education and health are largely closed, a primary area of gender inequality is in labor force participation. Hence, recommendations often include to reduce the tax burden for (predominantly female) secondary earners by replacing family taxation with individual taxation, thereby removing relative disincentives against labor market participation.

- In low-income and developing countries, recommendations often target gaps in both opportunities and outcomes. This includes equalizing school enrollment rates for boys and girls and boosting overall education levels. Other aspects include increasing female labor force participation through investments in infrastructure and transportation services to reduce the costs related to work outside the home (World Bank, 2012). Also, access to electricity and water sources closer to home can free up women's time for work outside the house and allow them to integrate into the formal economy. Adequate health care provision would help reduce time spent on providing informal care. Making communities safe for women increases their participation in work, education, politics, and recreation.

The Fund is increasingly advising in the area of gender budgeting. As part of the Fund's involvement with the UN High-Level Panel on Women's Economic Empowerment, it is committed to advancing research on gender budgeting. In addition, the Fund has begun training and capacity building through workshops in IMF regional technical assistance centers (CAPTAC and CARTAC) and technical assistance on gender budgeting, including recently in Austria, Bahrain, Cambodia, and Ukraine.

\section{The literature has discussed the many channels through which women's economic empowerment can positively impact the macroeconomy. For example, women are often more} likely than men to invest a large proportion of their household income in their children's education. Higher economic participation and earnings by women could therefore translate into higher expenditure on school enrollment for children (Aguirre and others, 2012; Miller, 2008; Rubalcava and others, 2004; Thomas, 1990). The impact of public transfer programs may also depend on the gender of the recipient (Duflo, 2003). Separately, lower fertility rates have been associated with higher education levels for girls, higher female labor force participation, and higher savings (Tertilt, 2005; Bloom and others, 2009). The importance of access to financial services has also been highlighted (Holloway and others, 2017). In aging countries, raising economic participation, including of women, can also directly yield growth and stability gains by mitigating the impact of the declining labor force. In turn, this helps to ensure the stability of the pension system (Steinberg and Nakane, 2012). 
14. Furthermore, the literature has shown how policy action can have material impact on gender inequality (Gonzales and others, 2015a). Policies to equalize enrollment rates for girls and boys would significantly boost overall education levels in low-income and developing countries, in turn supporting growth and stability. Das and others (2015) find that the female labor force participation rate in India would rise by 2 percentage points with an increase in spending on education of 1 percent of GDP of Indian states. In Bangladesh, female labor force participation has benefited from the government's Health and Community Services, and the participation rate of young women almost doubled in the late 1990s (World Bank, 2012). Other policies, depending on country-specific policy settings, include reducing the tax burden for (predominantly female) secondary earners by replacing joint with individual taxation (Elborgh-Woytek and others, 2013). Tax credits or benefits for low-wage earners are other measures that can be used to stimulate labor force participation (Clements and Stotsky, 2017).

15. However, policies would need to be carefully designed to avoid adverse distributional implications, which can ultimately undermine growth and stability. If not carefully calibrated, spending on education services can exacerbate income inequality-and high and rising levels of income inequality have in turn been linked to lower and less sustainable growth (Ostry and others, 2014). In this regard, in developing countries where low-income groups have less access to higher levels of education (including upper-secondary and tertiary education) than better-off groups, education services tend to accrue to people in the upper end of the income distribution. As such, while higher education is essential for accelerating economic transformation, it is important to also improve access to lower levels of education. Equalizing enrollment rates for boys and girls will also help boost overall education levels (Klasen and Lamanna, 2009; IMF, 2017a). Improving access to health services by expanding health coverage to low-income households can address inequality and reduce women's obligations to time-consuming informal health care.

\section{B. Gender Analysis at the Fund}

\section{A significant amount of analytical work has also been carried out at the Fund. This} work has covered both the causes and consequences of gender inequality at different levels of development (Kochhar and others, 2017). With respect to underlying causes, studies have examined how inequality in opportunities (education, legal rights) has impacted gender gaps in the labor market (Gonzales and others, 2015b) as well as which macroeconomic and labor market policies impact women's choice to join the labor market (Christiansen and others, 2016a; Khera, 2016). With respect to consequences, analytical pieces have associated gender equality with (i) higher growth, in particular in low-income countries (IMF, 2015b); (ii) lower levels of income inequality (Gonzales and others, 2015a); and (iii) higher levels of diversification (Kazandjian and others, 2016). Gender diversity in senior positions have also been associated with better financial performance of firms (Christiansen and others, 2016b) and greater bank stability (Sahay and others, 2017). 


\section{COVERAGE OF GENDER ISSUES IN COUNTRY PAPERS}

\section{A. Experience from Pilot Staff Reports}

17. Country teams have covered a wide range of topics. The following presents an overview of the coverage of gender issues in pilot studies. Box 2 presents good-practice examples for integration of gender issues in various country-specific contexts, highlighting also that gender issues concern both women and men. ${ }^{5}$

- Impact of female labor force participation on productivity and growth. Analytical work has identified drivers of female labor force participation and gender wage gaps as well as the impact on growth and inclusiveness (India, Morocco, Pakistan, and Rwanda). Teams have also estimated the impact of closing the gender gaps on productivity and growth (Canada, Chile, Germany, and WEAMU). For example, in the case of Canada, a one percentage point increase in the labor force participation rate among women with high educational attainment would raise Canada's overall labor productivity growth by 0.2 to 0.3 percentage point a year. As such, closing the gender gap could boost GDP in Canada by 4 percent; Japan by 9 percent; Pakistan by 30 percent; Niger by 32 percent; Iran by 40 percent; and Jordan by 45 percent. In the case of India, closing the gender gap in skills and access to formal finance would increase female economic participation and could boost India's GDP by close to 6 percent.

- Population aging. Left unaddressed, demographic change and aging populations in Japan, Macedonia, and Mauritius could weigh on potential growth by shrinking the labor supply and lowering productivity over the next decade. In this context, addressing gender gaps-including by removing disincentives to full-time work, increasing the capacity and quality of childcare facilities, and simplifying the entry process into the workforce (Japan); revising family leave policies to provide greater flexibility between parents (Macedonia); and promoting part-time work, increasing financial inclusion, and introducing paternity leave (Mauritius) — could increase female labor participation and mitigate or prevent such a growth slowdown.

- Financial inclusion. Teams have assessed the level of access to formal and informal financial services, microfinance, and mobile banking (India, Rwanda); impediments to access to formal finance through participation costs, borrowing constraints, and intermediation costs (Guatemala); and financial literacy among women (Jordan) — even in the context of overall high financial development (Mauritius). These analyses suggest that enhancing financial inclusion would increase female labor force participation, entrepreneurship, support small- and medium-sized enterprises, and improve competitiveness and boost potential growth (India, Pakistan).

- Labor market reforms and human capital accumulation. Country teams have analyzed ways to address skill mismatches, lack of private sector labor demand, the need for supply-side policies (including education to provide relevant skills) (Chile, Hungary, Iran, Mali), low human capital

\footnotetext{
${ }^{5}$ Country reports with additional details are listed in Table 1 . Issues presented in the note refer to their status at the time country reports.
} 
accumulation (Guatemala), labor market rigidities (India), and labor market duality (Japan) to increase female labor force participation in the formal sector and accumulate human capital.

- Impact of policy measures on gender equality and female labor force participation. Country teams have identified the need for increasing access to education; investing in infrastructure and information technology (Canada, India, Japan); reforming the tax system (individual taxation (Germany), working tax credits (Italy), eliminating spousal tax deductions (Japan)); and reassessing social spending measures (provision of childcare (Austria, Egypt, Hungary, Japan, Jordan, Poland)), long-term care for the elderly (Austria), and cash transfers targeting girls' education), to help address gender inequality and female labor force participation (Guatemala, Jordan, Morocco, Nigeria, Pakistan).

- Gender budgeting. The Rwanda and Morocco teams have highlighted the scope for improving gender budgeting. In Rwanda, the team highlighted how the authorities used the lessons learned from their initial implementation of gender budgeting to inform the current framework, which has been successful. Other teams have pointed to progress in enshrining gender budgeting into legal or formal budgetary frameworks. A recent example is Canada, which published its first gender statement in the 2017 federal budget. Other examples include Iceland and Nigeria. Iceland has restructured its budget practice (revenues and expenditures) to include formal adoption of gender budgeting, and Nigeria has introduced gender-sensitive budgeting targeted to women in the agricultural sector.

- Access to infrastructure. The Chile, Jordan, and Rwanda staff have highlighted how the availability of safe transportation and better roads and mobile networks help women access work. In India, the team pointed to the need for rural infrastructure investment in sanitation, access to drinking water, and transportation to reduce the time women spend on domestic tasks and to facilitate their access to markets.

- Legal barriers. Some teams noted that inequality in inheritance rights (Morocco, Niger, Pakistan), tax deductions or tax credits specific to men (Morocco), and regulations preventing women from working at certain institutions and positions (Niger) impact gender gaps in labor force participation. In at least half of WAEMU countries, women cannot be head of household. In contrast, in Latin America and the Caribbean, progress in equalizing legal rights for women and men has helped increase female labor force participation—though more needs to be done (Novta and Wong, 2017).

\section{In addition, country teams have considered gender inequality in the context of}

Fund-supported programs. For example, Egypt's program focuses on investing in public nurseries and is working toward implementing gender budgeting. Jordan's program contains a range of measures to reduce child-care costs, including publicly-subsidized nurseries for low-income employees in SMEs. In Niger, the program includes a structural benchmark on formulating a gender development plan.

\section{The analyses have been based on both macro- and micro-level gender-disaggregated data} from international organizations. At the macro level, data have generally been from Eurostat, ILO, OECD, World Bank, UNDP, and UNICEF, or where available from national authorities. This has allowed the analysis of labor force participation, access to education, health services, and political inclusion. At the micro-level, teams have benefitted from data from national household surveys, Global Findex, ILO, and Orbis, allowing to examine financial inclusion as well as firm-level indicators for female shares of employment in 
managerial positions. In addition, some country teams have collaborated or been in close dialogue with UN Women, the World Bank, and academic consultants, have drawn on cross-country analytical work by area and functional departments, and made use of Fund-developed in-house indices and toolkits, (e.g., gender inequality and gender budgeting indices and a financial inclusion toolkit) (see below).

\section{Box 2. Examples of Good Practice when Covering Gender Issues in Country Reports}

Examples of good practice in country consultations and Fund-supported programs made clear the macro-criticality of gender inequality, integrated gender gap analysis into policy discussions and recommendations, and increased traction with the authorities. Examples include:

India (2015, 2016, and 2017): integrating Fund policy recommendations into national strategies to realize higher and inclusive growth. India's staff reports built the case for gender equality as a macrocritical element to realize its growth potential. The team noted that improvements in public sanitation provisions that reduce women's time spent in home and care work by close to 10 percent can increase female labor force participation by 1.5 percent and real GDP by 1.4 percent. The 2015 Article IV staff report analyzed determinants of labor force participation using household data and unemployment surveys. The analysis showed urban-rural disparities in female labor force participation as well as a growing gender gap in participation rates. Integrating this finding into policy recommendations, staff proposed improving labor market flexibility and reorienting expenditure towards social spending, including expenditure on human capital (health and education) and public infrastructure. The 2016 Article IV staff report analyzed the macroeconomic impact of such policies on women's labor market outcomes and on aggregate economic activity in India and found these policies to increase female labor force participation and output. Traction with the authorities led to further analysis in India's 2017 Article IV consultation and integration of staff's policy recommendation into the government strategy, especially gender-targeted skills training programs and financial literacy programs. Specifically, staff's analysis showed that closing the gender gap in skills and access to formal finance increases female economic participation, which could boost India's GDP by close to 6 percent. A national fund has been established to provide micro-credit at affordable cost to poor women to support income generating activities. A new National Policy on Women is being formulated to promote gender equality.

Morocco (2017) and Rwanda (2017): collaborating and gaining traction with the authorities on gender budgeting. Staff reports for Morocco and Rwanda assessed the efficiency of fiscal measures to promote and influence gender equality.

Morocco is notable for having the first and most developed gender budgeting initiative in the region. However, staff diagnostics pointed to very low and declining female labor force participation rate over the past decade. The report identified that such trend partly reflects poor education and skills mismatches. It highlighted the need to increase the efficiency of public spending on education and to enhance teachers' training, recruitment, and evaluation. Furthermore, it noted the need to foster public-private partnerships for curriculum design and apprenticeships, which could help align worker skills with private sector needs.

Rwanda has had notable success in broadening gender issues into each level of government operations, reducing gender inequality to the lowest level in sub-Saharan Africa. Nonetheless, staff analysis pointed to economic gains from further reducing gender inequality, which could boost per capita GDP growth by $1 / 2$ percentage points (Rwanda, 2017 Selected Issues). Specifically, increasing access to quality health and education services and higher financial inclusion could boost female labor force participation in higher value-added economic activity beyond agriculture. 
Box 2. Examples of Good Practice when Covering Gender Issues in Country Reports (concluded)

Mongolia: considering gender equality in Fund-supported programs. In Mongolia's Fund-supported program, staff considered the implications for gender equality of policies under the program. They found that, in general, program policies helped promote equality by creating conditions for more inclusive growth, financing female entrepreneurs, and supporting better social outcomes. The move to progressive income taxation is also expected to reduce wage gaps, and a better capitalized banking sector and diversification beyond mining will support higher female participation in the economy. The program also has a catalytic role in unlocking other contributions from international financial institutions (e.g., Asian Development Bank).

Norway (2017): increasing high-quality labor supply (of both genders) to promote growth. Norway is a case where gender was not considered macro-critical but was a priority for the authorities. Staff noted that Norway ranks first globally in women's economic participation and opportunities, but that women and men face very different labor market challenges. While female employment rates are high, considerable potential remains to increase full-time work incidence and foster women's upward mobility to reduce persistent wage gaps. In addition, there is notable potential to reintegrate men, whose employment rates have declined after the global crisis and the downturn in the oil sector during 2014-16, which increased youth unemployment. To increase working incentives for women, staff pointed to the need to increase care options for the youngest children and to make childcare hours more flexible. For men, targeted active labor market policies and lifelong learning opportunities could be further enhanced to improve search and matching efficiency. For youth, the team noted that reforms to improve the quality of the education system are important to enhance their marketable skills and lower dropout rates.

\section{Tailored policy recommendations to increase female labor force participation and enhance gender equality have included the need to:}

- Enhance oversight, carry out audits, and monitor gender budgeting efforts to boost female labor force participation and financial inclusion (Canada, Iceland, Morocco, Rwanda);

- Move towards a system of individual taxation (Germany, Japan) or working tax credits (Italy), eliminate spousal deduction for tax and social security (Japan), and reform gender-discriminatory tax policies and laws (Morocco, Jordan, Pakistan);

- Increase female education and training (Canada, Chile, Hungary, India, Mali, Pakistan, WAEMU), supported by national plans to foster job creation (Iran, Jordan, Rwanda);

- Expand after-school programs (Germany), extend early childhood education and/or childcare services (Austria, Canada, Costa Rica, Egypt, Guatemala, Hungary, Italy, Japan, Mauritius, Pakistan), remove mandated employer-provided childcare (Chile), and encourage men to participate in family care (Japan);

- Invest in infrastructure (Chile, Costa Rica, India, Pakistan, Morocco, WAEMU);

- Review labor regulations to facilitate job creation and retain talents (Iran), improve flexibility in work hours (Canada, Chile, India, Jordan, Mauritius), and phase out early retirement for women (Hungary); and 
- Strengthen female inheritance rights on immoveable property to eliminate discriminatory effects of legal restrictions (India, Pakistan), address legal inequalities that inhibit women from being the head of household or that inhibit women's ownership of property (Morocco, Niger). IMF research (Novta and Wong, 2017) also pointed to the need for further strengthening women's property rights and laws protecting women from discrimination in many Latin American countries.

\section{Staff engagement with the authorities on gender issues has helped create awareness of the macro-criticality of these issues, and in some instances gained policy traction. Staff has} held discussions during Article IV consultations, presented Selected Issues Papers and working papers, conducted outreach to other relevant stakeholders (including CSOs, labor unions, and women's groups), and organized gender-related events in collaboration with national authorities and other development partners. A number of countries have adopted policies to support economic empowerment by women, in some cases reflecting the increased traction of the Fund's

gender-related policy advice. For example, gender objectives were included in national employment and planning strategies (Cabo Verde, Jordan) and were reflected in fiscal policies-including through the expansion of childcare facilities (Austria), public subsidies to childcare (Japan), and the introduction of gender-responsive budgeting (Pakistan)—and labor market reforms, including by promoting flexible work arrangements (Japan). And while in some countries (Iran, Morocco), the authorities found policy recommendations difficult to implement due to differences in cultural and religious norms, staff analysis has been well received and has increased awareness of gender issues. In addition, several countries engaged in Fund-supported programs have included structural conditionality to promote female labor force participation (Jordan, Egypt, Niger).

22. Several lessons stand out from the pilot experience. Positive experiences include the benefits from drawing on expertise of other agencies, including through use of their databases, which facilitated learning and improved the quality of analysis and policy advice. Support from the Gender Advisory Group and intra-departmental collaboration has contributed to peer learning and knowledge sharing. This has created synergies and helped keep resource costs manageable for several teams. In addition, country teams have pointed to the importance of early engagement with the respective Executive Directors to leverage support and motivate the analytical agenda. Dialogue with concerned ministries and external experts before, during, and after Article IV missions has helped gain traction with the authorities, share knowledge, and explore cultural sensitives to better tailor policy advice. That said, areas for improvement remain, including the need to enhance data sharing through Knowledge Exchange. Cross-country analytical work, including through intradepartmental collaboration and regional studies, helps support knowledge sharing and keep resource costs down, and should continue (Box 3). 


\section{Box 3. Leveraging Cross-Country Work on Gender in Bilateral Surveillance}

Several country teams have leveraged cross-country analytical work when providing bilateral advice in Article IV consultations. Going forward, such an approach is highly encouraged as it supports knowledge sharing and reduces resource costs for individual country teams.

Europe. Two cross-country studies have been particularly beneficial for bilateral policy advice.

- A joint EUR/SPR departmental paper (Christiansen and others, 2016c) analyzed the drivers of female employment in Europe, the impact of policies, and the importance of gender-diversity in senior positions for corporate performance. This allowed the Poland team to deepen their policy recommendations (2016 Article IV) at a time when the authorities were considering increasing cash child allowances. The analysis also supported the Italy team (2016 Article IV) in extending the analysis on the importance of women in senior position to a sample of Italian companies. The Sweden team presented results from an underlying working paper (Christiansen and others, 2016b) to the authorities to engage in discussions on the link between gender diversity in senior positions and financial performance.

- In the context of the authorities' goals of income convergence with advanced Europe, amid declining working age populations and sizable emigration, a working paper on increasing women's role in the Western Balkan economies (Atoyan and Rahman, 2017) pointed to a high share of inactive or unemployed women in the region and examined which policies could help alleviate this phenomenon. This work fed into the Serbia (2017 Article IV) and FYR Macedonia (2017 Article IV) teams' analyses of underlying drivers of existing gender gaps and policy advice to ensure full participation of the available workforce.

Middle East and North Africa. The 2013 Regional Economic Outlook for the Middle East and Central Asia (IMF, 2013c) estimated the potential output gains from narrowing gender gaps in the labor market in the MENAP region and analyzed the importance of various policy measures to help increase female labor force participation. In turn, this supported individual teams' efforts to estimate the potential macroeconomic impact of higher female labor force participation at the country level. An example includes Iran (2016 Article IV), for which the team found that bringing the female employment rate to male levels could raise GDP by around 40 percent.

Sub-Saharan Africa. The 2015 October Regional Economic Outlook for sub-Saharan Africa (IMF, 2015b) included a cross-country analysis of the impact of income and gender inequality on growth in low-income countries. This analysis was applied by the WAEMU (2016 Selected Issues) and Rwanda (2017 Selected Issues) teams, with both teams quantifying the potential gains in per-capita GDP growth from reducing gender inequality.

Western Hemisphere. Two external cross-country papers were leveraged in the Argentina and Chile teams' analyses.

- Aguirre and others (2012) estimated the potential impact on GDP from closing the gender employment gap for a number of countries and considered the types of measures needed to empower women across five country clusters based on 128 countries. The Argentina team (2017 Article IV) leveraged this analysis by quoting their estimate that increasing female employment to male employment levels would raise GDP per capita in Argentina by approximately 12 percent.

- A University of Barcelona (UB) Economics Working Paper on the Aggregate Costs of Gender Gaps in the Labor Market (Cuberes and Teignier, 2014) provided quantitative estimates of the effects of gender gaps on aggregate productivity and income per capita. In turn, referencing this study, the Chile team (2015 Article IV) noted that the GDP losses from economic gender gaps were estimated at 17 percent of GDP for Chile and that closing the female labor force participation gap vis-à-vis the average among Argentina, Brazil, Colombia, Mexico, Peru, and Uruguay (LAT6) would result in a cumulative GDP gain of about 3 percent over the medium term, relative to the baseline. 


\section{B. Covering Gender Issues in Staff Reports}

23. The extent of coverage of gender issues in country reports is expected to be linked to the degree of their macroeconomic significance. Teams should cover gender issues selectively where they are deemed macro-critical, as is the case with the many other analytical topics that are featured in Article IV reports. Where gender issues are not considered macro-critical in a given country context, coverage is not expected. As such, coverage of gender issues is not anticipated in every staff report every year. Rather, in-depth coverage is envisaged only in a limited number of cases per year. Should a particular issue of macroeconomic relevance arise where staff does not have expertise, staff would be expected to flag the issue in the staff report, with the analysis focused on the economic aspects and relying on other institutions with relevant expertise for policy advice. After the Article IV consultation cycle, country teams that have deemed gender issues to be of macro-critical importance are expected to follow and report on subsequent progress and implementation of policy recommendations, though updates in country reports are not required on a regular basis.

24. When country teams incorporate gender issues in surveillance, country papers should make clear the macro-criticality of gender issues as part of the overall narrative. Given the importance of gender issues for the given country, focus should be on ensuring integration with the main storyline of the country paper. The narrative should clearly indicate how gender issues fit in the overall macroeconomic picture and why addressing gender issues is of macro-critical importance. It will be important to report existing gender gaps, outline transmission channels to growth and economic stability, and identify specific barriers that cause the gaps. Policy advice should include a discussion of how to remove barriers and reduce gaps as well as the impact of proposed policy measures on the economy.

\section{Discussions of gender issues should be guided by the following questions:}

- How do gender issues fit in the overall macroeconomic picture and what are the transmission channels? What are the main gender-related challenges and what are the potential channels through which gender issues impact the economy? This can, for example, include productivity, labor force participation, diversification of the economy, and the need to reduce inequality. Recent examples from country reports include countries (i) with aging populations that would need to boost their labor force to sustain growth (Japan, Mauritius, Poland); (ii) where unlocking female labor force participation can reinvigorate growth (India); (iii) where reducing gender gaps in the labor market can increase labor productivity (Canada); and (iv) where there is a need to diversify the economy (Morocco.

- How are gender gaps measured? The report should be clear on diagnostics, establishing the facts. To the extent possible, the analysis should rely on cross-country data (e.g. World Bank, ILO, and OECD) as well as country-specific labor statistics and household surveys. Such data would allow a comparison with peers and provide a baseline against which the impact of specific 
policies could be measured. ${ }^{6}$ In addition, teams are encouraged to draw on existing country-level analytical work (India, Mauritius, Morocco, Canada) and cross-country papers (e.g., Staff Discussion Notes; Regional Economic Outlooks), enriching the findings with more granular country-specific details. ${ }^{7}$

- What are the specific barriers that cause the existing gender gap? The list of potential barriers includes-but is not limited to-legal rights, taxation practices, access to education and health care, childcare options, or infrastructure. Lack of basic legal rights could prevent women from joining the formal labor market or becoming entrepreneurs, which in turn would impact growth and productivity (Pakistan, WAEMU, Morocco). Access to financial and social services could have significant implications for labor productivity (Pakistan, Mauritius). A taxation structure that penalizes second income earners in the household could lead to lower female employment (Germany, Italy). Lack of public infrastructure (India) or unsafe public transportation (Jordan, Egypt) could also prevent women from joining the labor force.

- What are the policies to reduce and eliminate those barriers? What would be the outcome if these policies are implemented? Policy recommendations would likely vary depending on the diagnosis of the underlying reasons for the gaps and available policy space. In emerging and developing countries, recommendations may include investing more in girls' education, health care, and infrastructure. In advanced economies, policies that encourage greater parity between paternity/maternity leave and investing in high-quality childcare could support a more rapid return to work among mothers. The impact of gender budgeting procedures on the allocation of resources could also be considered. In addition, it is desirable to support policy recommendations with an assessment of how these policies may impact macroeconomic performance. $^{8}$

- How do policy recommendations fit in the overall policy mix and what are the policy interactions? The report should aim at linking gender policies to fiscal costs, financial sector performance, and other polices. The synergies with other structural policies are particularly important to consider, as gender-related policies are often an integral part of broader structural reforms. For instance, the analysis of the impact of various policies on female labor force participation and output in the Western Balkans (Atoyan and Rahman, 2017) shows that the impact from closing gender gaps is significantly higher if the overall quality of institutions is improved.

\section{Country teams should also think about the impact of other macro-economic policies}

on gender. Some policies recommended by staff to support growth and stability may have

\footnotetext{
${ }^{6}$ For instance, Atoyan and Rahman (2017) used both macro- and micro-level data to analyze gender gaps and their effect on productivity and growth.

${ }^{7}$ Also, several country reports have used the financial inclusion toolkit developed by the African Department (AFR) (e.g., Rwanda, Cameroon).

${ }^{8}$ For instance, it is estimated that female labor force participation in India would rise by 2 percentage points if Indian states increased education spending by 1 percent of GDP (India).
} 
differential gender impact that could exacerbate gender inequality. For example, budget cuts on subsidies and social programs, cuts in the public-sector wage bill, or increasing transportation fees might have larger impact on women. In these instances, staff may consider an alternative policy mix to prevent such negative externalities or-if the former is not feasible-suggest some mitigating measures (see a new model tool applied to Argentina (Box 6)). In addition, policy design may need to consider potential trade-offs between government conditionality to improve targeting, such as means-testing, and their gender impact.

\section{Other issues to consider:}

- Authorities' views. Staff reports should be transparent about the authorities' views and any disagreements on the proposed gender policies.

- Cultural considerations. While all policy recommendations should be considered against the backdrop of countries' cultural and religious norms, the reports should present the facts and show the impact of proposed policies. In many countries, the scope for policy to increase female labor force participation is large, independently of social attitudes towards working women.

- Leveraging external expertise. To the extent possible, country teams should draw on expertise at the World Bank, UN Women, and other agencies. In addition, teams are strongly encouraged to discuss with and get advice from think tanks, CSOs, and other policy research institutions in the countries with good knowledge of the local context.

\section{When gender inequality is deemed macro-critical and teams opt to cover gender} issues in-depth, country reports should present key gender indicators. To guide the reader, country reports discussing gender gaps should aim to clearly establish these gaps, possibly by including a table with key indicators (Box 4). While specific indicators of importance may vary depending on country circumstances, indicators could usefully cover general statistics (e.g., population details), gaps in opportunities (e.g., education and legal restrictions), and gaps in outcomes (e.g., labor force participation and unemployment rates). Information on access to finance and health indicators (e.g., maternal mortality rate) would also help provide a comprehensive view, as would potential gender budgeting initiatives. The Selected Economic Indicators table should include levels of female labor force participation, where data are available.

29. Country teams are encouraged to provide occasional progress reports. In Article IV consultations in following years, staff is expected to monitor and provide updates on progress in the areas they have highlighted, as their coverage in surveillance presumes that they have been deemed macro-critical. In this respect, staff should inquire with the authorities on actions taken to close the gender gaps. As progress in gender indicators and policy reforms are not likely to advance rapidly over time, country teams are not expected to cover gender issues in depth every year and progress reports are not required on a regular basis. 


\section{Box 4. Example of Gender Indicators in Country Reports}

When teams plan to cover gender issues in country reports, they should include a table with selected gender indicators. While relevant indicators may vary by country, all reports discussing gender issues should provide indicators to, at least, assess labor force participation. Please see below a suggested example.

Country Name: Selected Gender Indicators

(Percent, unless otherwise indicated)

2000

\section{General}

Population (million people)

Female share in total population

Total life expectancy (years)

Male

Female

\section{Opportunities}

School enrollment (girl-boy ratio)

Primary

Secondary

Tertiary

Number of legal restrictions on women (from

Women, Business and the Law)

Gender gaps in financial inclusion (bank accounts,

saving/borrowing)

Health (especially for LICs)

Maternal mortality rate

Fertility rate

Adolescent fertility rate

\section{Outcomes}

Total labor force participation rate

Male

Female

Total unemployment rate

Male

Female

Youth

Female seats in parliament (share of total seats)

Ratio of female to male income

Sources: 


\section{ENGAGEMENT WITH AUTHORITIES AND OTHER STAKEHOLDERS}

30. Teams should consult early with the authorities on the planned focus on gender issues in the upcoming Article IV consultations. Teams should seek the authorities' views on the macro-criticality of gender issues and explore the channels through which gender gaps can affect economic stability as well as the drivers of such gaps. In this respect, teams have benefitted from early engagement with the authorities, as is also the case when other (non-gender) analytical issues are proposed to be explored in depth. Such engagement could take the form of reaching out to Executive Directors or discussing the issues in a staff visit prior to the Article IV consultation. Where available, teams can reach out to authorities through local IMF Resident Representative offices.

31. In addition, teams can benefit from reaching out to other stakeholders. External partners with expertise on gender issues can help gauge the economic significance of these in the given country context, thereby supporting staff's analysis. Thus, it could be beneficial to establish early contact with organizations such as the World Bank, UN Women and ILO-which have offices both in Washington, D.C. and locally in many countries — or third-party stakeholders (CSOs, unions) during staff visits preceding Article IV consultations. Country authorities may also have a role in helping to form partnerships with local experts.

\section{RESOURCES AVAILABLE TO COUNTRY TEAMS}

32. The following describes many of the internal and external resources available, including data, toolkits, and existing analytical work.

\section{A. Internal Resources}

33. The Gender Advisory Group supports knowledge sharing. The central role of the Gender Advisory Group is to aggregate and disseminate data, knowledge, and analytical tools, drawing on expertise within and outside the Fund and leveraging work of international organizations and multilateral fora. An important role is also to facilitate peer learning by country teams by providing an opportunity to present their work at various stages of completion to receive feedback from experts and other country teams. The Advisory Group could also facilitate collaboration with external experts.

34. The Gender Knowledge Exchange (KE) site provides easy access to data. The gender KE site - accessible only to IMF staff-allows direct access to data, toolkits, and cross-country analytical work. It provides a comprehensive list of macro- and micro-level data for gender analysis, including on gender gaps in education, financial inclusion, employment, entrepreneurship, political representation, and health outcomes. In addition, the site provides IMF staff with links to working papers, Staff Discussion Notes, Article IV staff reports from the two completed waves of country pilots, and external resources.

35. The IMF's external website highlights upcoming events and recent publications. In addition to resources through the internal KE site, the Fund's external website has a section focused on gender issues to provide users with information on upcoming events (conferences and seminars), publications, 
podcasts, speeches, infographics, and media coverage of staff work. IMF Data provides direct access to information on gender budgeting and gender equality.

36. Existing analytical work covers a wide range of issues. A recent book (Kochhar and others, 2017) offers a collection of more than 20 IMF cross-country and country-specific case studies. These cover many aspects of gender issues, including linkages between macroeconomic outcomes (such as growth, income inequality and economic diversification) and gender inequality as well as potential policies to mitigate gender inequality, drawing on both multilateral and bilateral surveillance. An IMF staff paper on "Gender Budgeting in G7 Countries" presents an overview of gender-responsive budgeting concepts and practices in the $\mathrm{G} 7$ countries (IMF, 2017b). Please see below a few examples of cross-country studies at the Fund that focus on gender inequality.

- Aslan and others (2017). Discusses gender gaps in financial inclusion and income inequality.

- Christiansen and others (2016c). Investigates the drivers of female labor force participation in Europe and associations between greater gender diversity in senior corporate positions and firm performance.

- Clements and Stotsky (2017). Examines fiscal measures to stimulate economic participation by women.

- Gonzales and others (2015a). Examines how gender inequality drives income inequality above and beyond determinants previously identified in the literature.

- Gonzales and others (2015b). Explores equal laws and female labor force participation.

- Kazandjian and others (2016). Discusses that gender inequality, both in outcomes and in opportunities, negatively impacts export and output diversification in low-income and developing countries.

37. Data and toolkits provide easy access to cross-country comparisons. A number of data sources are listed in Box 5. In addition, Big Data may have the potential to help address development challenges and meet demands for compiling Sustainable Development Goals (SDG) indicators, such as gender equality (Hammer and others, 2017). Further, toolkits on gender budgeting, equality, and financial inclusion —available from the gender KE Site—facilitate benchmarking countries against international experiences.

- Gender budgeting and equality. This toolkit has two parts: (i) a dataset on global gender budgeting efforts and (ii) a panel dataset with two time-consistent gender equality indices:

(i) The gender budgeting dataset contains information on 84 gender budgeting initiatives around the world, of which 23 initiatives are investigated in depth in six regional surveys.

(ii) The gender equality indices dataset contains two composite indices: (a) a Gender Development Index (GDI) and (b) a Gender Inequality Index (GII). Both were initially developed by the United Nations Development Programme (UNDP) and have been extended in a time-consistent manner to cover 140 countries over 1990-2013. 


\section{Box 5. Selected Data Sources}

A number of cross-country databases exist at both the macro- and micro-economic level. Below is a list of key databases and their content.

\section{INTERNATIONAL MONETARY FUND}

Gender Knowledge Exchange. On the Fund's intranet. Provides direct access to data, toolkits, and crosscountry analytical work.

IMF DATA. Provides information and data on gender budgeting and gender equality across countries and time.

WORLD BANK - The World Bank in Gender

Gender Data Portal. Summarizes gender indicators from World Development Indicators and other sources. These include economic structures; education; health and related services; public life and decision making; human rights of women and girls; and demographic indicators. Covers a wide range of indicators for 263 countries from 1960-present. The Little Data Book on Gender presents gender-disaggregated data for more than 200 economies on the six core areas contained in the Gender Data Portal.

ADePT Gender. Produces tables and graphs using household surveys to diagnose and analyze gender inequalities.

Women, Business and the Law. Covers 143 countries and three reports $(2010,2012,2014)$. It includes legal information on accessing institutions; using property; getting a job; incentives to work; building credit; going to court; and protecting women from violence. For 100 countries, "Accessing Institutions" and "Using Property" are available for 1960-2010.

World Bank Enterprise Surveys. Provide information on women's entrepreneurship and economic participation based on surveys of more than 135,000 firms in 135 countries.

Global Findex. Measures how adults in 148 countries save, borrow, make payments and manage risk. Indicators are provided by gender and other dimensions.

\section{ORGANIZATION FOR ECONOMIC CO-OPERATION AND DEVELOPMENT (OECD)}

Social Institutions and Gender Index. Includes rankings in 2012 and 2009 for over 100 countries. Contains information on discriminatory family code; restricted physical integrity; son bias; restricted resources and entitlements; and restricted civil liberties.

Employment by gender. Includes short-term labor market statistics; quarterly and real-time.

Program for International Student Assessment (PISA). Triennial international survey to evaluate education systems worldwide by testing the skills and knowledge of 15 -year-old students.

\section{INTERNATIONAL LABOUR ORGANIZATION (ILO)}

Key Indicators of the Labor Market. Data over 1980-2010. Compiles information from international repositories on labor force participation; employment/population; employment status; employment by sector and occupation; part-time workers; hours of work; employment in informal economy; unemployment; youth unemployment; long-term unemployment; time-related underemployment; inactivity; education attainment/illiteracy; average monthly wages; hourly compensation costs; labor productivity; and poverty, income distribution, and working poor.

TRAVAIL. Working Conditions Laws Database. Contains legal information on maternity protection for more than 100 countries. Data cover maternity leave; parental, paternity, adoption leave; right to part-time work; cash benefits; medical benefits; breastfeeding; health protection; and non-discrimination and employment security. 


\section{Box 5. Selected Data Sources (concluded)}

ILOSTAT. Covers more than 200 countries over 1969-2008. Includes projections for 2013-2030 for population and the labor force by sex and age.

- Annual indicators: Data on population and labor force; employment/unemployment; outside labor force; youth; working time; earnings/employment-related income; occupational injuries; trade unions, collective bargaining; and working poor.

- Short-term indicators. Data with latest monthly/quarterly/semi-annual statistics on working-age population; economically active population; employment/unemployment; working age population not economically active; working time; and earnings/employment-related income.

\section{UNESCO}

UNESCO Institute for Statistics. Data generally available for up to 200 countries, starting in 1998 :

- Gender in Education. Out-of-school children; teachers; access to education; participation; progress; and outcomes.

- Gender in Science. R\&D personnel by sector; researchers by sector; researchers by qualification; researchers by field of science; technicians and equivalent staff; and other supporting staff.

\section{OTHER}

Eurostat. Data on gender gaps in education, labor market, earnings, and health. For EU member states between 2006 and 2016.

Global Gender Gap Report. Focuses on relative gender gaps across four key areas: health, education, economy, and politics. Covers 2006-16 and ranks up to 144 countries.

Luxembourg Income Study. Harmonized micro data for 34 countries. Data cover population composition; employment rates; weekly hours; poverty rates; employed or not characteristics; annual earnings; youth characteristics.

Orbis. Data at the company level with indicators for size of company. Allows to consider the gender composition in senior positions and at the Executive Board.

The Economist Intelligence Unit. The Women's Economic Opportunity Index ranks 128 countries 2010 and 2012.

UNICEF. Data on education and health, including maternal health and water and sanitation.

United Nations Development Programme (UNDP). Provides the Human Development Report and the related Gender Inequality and Gender Development Indices, which comprise several dimensions of gender inequality (health, empowerment, and labor market).

United Nations Gender Inequality Index. Up to 186 countries ranked for 2000-2013.

UN Women Gender Equality Evaluation Portal. Makes available more than 350 evaluations on what works to achieve gender equality and women's empowerment. In addition, UN Women regularly publishes a report on the Progress of the World's Women.

USAID. Publishes Gap Analyses to facilitate the discussion on where foreign assistance resources ought to be allocated. Gender inequality is a frequently discussed topic. 
- Financial inclusion. Building on the World Bank's rich micro-level data on financial inclusion for 140 countries, the financial inclusion toolkit provides an easy means to (i) benchmark countries' state of financial inclusion across gender and income groups; (ii) relate gaps in financial inclusion to macroeconomic indicators such as per-capita output and economic growth; and (iii) point to possible constraints to financial inclusion overall, and for women across different demographic groups in particular.

38. In addition, a new micro-founded general equilibrium model allows teams to analyze the impact of various fiscal policy actions. Recently, SPR has developed a Dynamic Stochastic General Equilibrium model (Box 6). With this model, teams can assess not only the overall macroeconomic and distributional impact of changes in tax policy or transfer programs but also the impact on gender inequality, measured through labor force participation rates of women and men and gender wage gaps.

\section{Alongside, capacity development continues to support the membership. Work has} started in integrating the gender dimension into public financial management technical assistance. In Cambodia, the Fund has advised on how to adapt the government financial management information system to define and monitor cross-cutting gender-related programs. In Austria, an assessment of the government's gender budgeting framework was done as part of the fiscal transparency evaluation. In Ukraine, topics included the implementation of the gender budgeting project and its relationship with the medium-term budget reform. Overall, following technical assistance projects, teams would be expected to leverage recommendations from these as part of policy recommendations in staff reports, where relevant. Furthermore, the Fund is conducting workshops on gender budgeting in regional centers, and many centers are incorporating gender considerations in their work programs. Finally, the IMF Institute for Capacity Development (ICD) is planning an internal training course on Inclusive Growth for staff in the spring of 2018, following an external course that has been offered since 2013. This course would include discussions about gender inequality as one dimension of inequality and inclusiveness; how gender issues are impacted in the context of growth and job diagnostics; and gender budgeting as part of how policies can mitigate inequality.

\section{B. External Resources}

\section{Collaboration with international organizations and other external partners remains}

vital. As such, the Fund continues to build on our existing partnerships, including with the World Bank and UN Women. Examples include country-level collaboration, peer-learning events, research projects, and conferences. To mention a few:

Country-level collaboration. Some pilot teams were closely engaged with other international organizations, including in terms of discussions and close dialogue with the World Bank, the EBRD, ILO, UNFPA, UNDP, UNICEF, trade unions, and civil society (India). In Rwanda, the team co-organized a workshop with UN Women during the Article IV mission, which brought together government officials with representatives from international organizations, including the World Bank and ILO, to discuss the main challenges to gender equality in the country. UN Women provided detailed 
Box 6. A Dynamic Stochastic General Equilibrium Approach to Gender Inequality ${ }^{1}$

To assess the macroeconomic, distributional, and gender impacts of macroeconomic policies and reforms, staff has developed a micro-founded general equilibrium framework. This Box describes the details of the model with a recent application to Argentina.

The Dynamic Stochastic General Equilibrium (DSGE) model is a micro-founded general equilibrium framework with heterogeneous agents. The framework is fairly general, allowing for customization to distinct economies. It includes different sectors and a distinction between formal and informal production. Agents differ from each other in many aspects: gender, area of residence (urban vs. rural), innate abilities, endogenous accumulation of human capital, income, and generation.

The model is calibrated using both micro and macro data of the particular country of study. This includes statistics such as the size of sectors relative to GDP; the country's income distribution; rules regarding taxation, the social security system, and cash transfer programs; labor force participation; the gender wage gap; and family consumption patterns.

The broad features of the model allow country teams to analyze the impact of fiscal policy actions. Potential policy shifts to be studied include changes in consumption, income, or corporate taxes and modifications of transfer programs and pensions systems. The model allows to examine the resulting impact on economic growth, the income distribution, female labor force participation, the size of formal vs. informal sectors, and human capital and education distributions. Impacts can be assessed for urban vs. rural residents, women vs. men, and older vs. younger generations. Furthermore, the framework allows to understand the channels and mechanisms through which inequality is likely to be affected. Overall, this can support teams' assessments of the design of complementary policies, thereby helping to ensure that a given reform package can boost growth without harming inequality.

The model has been applied to Argentina. Based on the model, staff concluded that a hypothetical reform that reduces the labor tax wedge in Argentina could lead to higher economic growth through the expansion of the formal sector and a lower gender wage gap (Kolovich and others, 2017).

- The hypothetical reform comprised (i) reducing employees' social security contribution rate by 3.4 percentage points; (ii) lowering employer's social security contribution rate by 5.2 percentage points; and (iii) cutting the main tax deduction by half.

- Results from the simulations showed that (i) GDP would increase 1.2 percent following the reform; (ii) women in the formal sector, who in the model face costs associated with working (for example owing to the need to care for children), would respond more than men, as the benefits from higher after-tax income increasingly outweigh the costs from working, increasing their average hours worked by 11.6 percent; and (iii) inequality (as measured by the Gini coefficient) would not be aggravated by the reform.

${ }^{1}$ Prepared by Lisa Kolovich, Vivian Malta, and Marina Mendes Tavares. 
comments on the team's gender analysis. The Niger team had close discussions with local nongovernmental organizations (NGOs) seeking to promote gender equality (CONAFE), child protection (CONIDE), and to end slavery (Timidria). The Cabo Verde team cooperated with an external expert on research related to gender inequality.

- Peer-learning. The Fund has partnered with the Rwandan Ministry of Gender and Family Promotion, UN Women, and the Uongozi Institute in Tanzania to offer a peer-learning conference in Kigali, Rwanda, focused on best practices in terms of gender policies and aiming at establishing a network for gender practitioners in sub-Saharan Africa.

- Research. The Fund and the United Kingdom's Department for International Development have partnered on a research project that examines macroeconomic issues in low-income and developing countries, including related to gender. Part of the project was a two-year study on gender budgeting around the world. To complete this work, the Fund has invited the World Bank, UN Women, and civil society representatives to serve on the advisory board. As noted above the Fund's SPR department has also developed a Dynamic Stochastic General Equilibrium model, which can help assess the impact of policies on gender inequality.

- Conferences. The Fund hosted a two-day conference on gender and macro issues in March 2017. As part of a preconference event, the Fund invited 14 researchers from sub-Saharan Africa for a day-long discussion on how the IMF can better partner with CSOs, academia, and government officials to advance gender equality objectives. In addition, the Fund held a major conference on Fiscal Policies and Gender Equality in November 2016, including panel discussions with government officials, academics, development agencies, the Fund's Managing Director, the Executive Director of UN Women, and the Executive Director for Oxfam Canada. Key take-aways for low-income countries included the priority to ensure adequate spending on gender-related goals in education, health care, and infrastructure. For advanced economies, the focus should be on the revenue side (e.g. on tax reforms to help low-income families, which are disproportionately headed by women, and on reduced taxation of secondary earners in households, which tend to be women). 


\begin{tabular}{|c|c|c|c|}
\hline \multicolumn{4}{|c|}{ Table 1. First- and Second-Wave Pilots } \\
\hline Country $^{1}$ & Coverage of Gender Issues & Engagement with the Authorities & Good Practices \\
\hline \multicolumn{4}{|l|}{ AFR } \\
\hline $\begin{array}{l}\text { Cabo Verde } \\
\text { (2016 Article IV } \\
\text { Staff Report and } \\
\text { Working Paper) }\end{array}$ & $\begin{array}{l}\text { Estimated potential economic gains } \\
\text { from closing the gender gap. }\end{array}$ & $\begin{array}{l}\text { Interest and traction with the authorities as } \\
\text { evidenced by the integration of some of } \\
\text { the team's policy recommendation into the } \\
\text { draft National Planning Policy document. }\end{array}$ & $\begin{array}{l}\text { Collaboration with IFIs and national } \\
\text { authorities. Leveraging analytical } \\
\text { work within and outside the Fund }\end{array}$ \\
\hline $\begin{array}{l}\text { Mali } \\
\text { (2015 Selected } \\
\text { Issues) }\end{array}$ & $\begin{array}{l}\text { Examined gender inequality, and } \\
\text { identified gaps in education and } \\
\text { demographics as main constraints to } \\
\text { female labor force participation. } \\
\text { Recommendations included closing the } \\
\text { gap between the demand for and the } \\
\text { provision of contraception. }\end{array}$ & $\begin{array}{l}\text { Stakeholders expressed reservation to } \\
\text { policy advice addressing high fertility and } \\
\text { contraception gap for cultural reasons. }\end{array}$ & \multirow{3}{*}{$\begin{array}{l}\text { 1) Data sharing through knowledge } \\
\text { exchange and REO worked well. } \\
\text { 2) Supportive environment from } \\
\text { senior staff within the department on } \\
\text { the pilots. } \\
\text { 3) Seminars or other regular meetings } \\
\text { with the interdepartmental gender } \\
\text { group; presentations made in AFR's } \\
\text { inclusive growth network. }\end{array}$} \\
\hline $\begin{array}{l}\text { Mauritius } \\
\text { (2015 Article IV } \\
\text { Staff Report) }\end{array}$ & $\begin{array}{l}\text { Estimates show real GDP in Mauritius } \\
\text { has been } 22 \text { to } 27 \text { percent lower } \\
\text { compared to a situation without gender } \\
\text { gaps in labor force participation and } \\
\text { entrepreneurship. Closing the gaps } \\
\text { could mitigate negative effects from } \\
\text { demographic change. Policies need to } \\
\text { create a level playing field for men and } \\
\text { women (paternity leave, high quality } \\
\text { child support) in the labor market and } \\
\text { reduce skill-mismatches to increase } \\
\text { female labor force participation. }\end{array}$ & $\begin{array}{l}\text { The authorities were interested in staff's } \\
\text { analysis but highlighted cultural constraints } \\
\text { of some of the suggested policies (e.g., the } \\
\text { introduction of paternity leave). }\end{array}$ & \\
\hline $\begin{array}{l}\begin{array}{l}\text { Nigeria } \\
\text { (2016 Article IV }\end{array} \\
\text { Staff Report) }\end{array}$ & $\begin{array}{l}\text { Article IV consultation included gender } \\
\text { gap analysis in annex to Staff Report. } \\
\text { Recent efforts have made progress in } \\
\text { promoting female labor force } \\
\text { participation. A conditional cash transfer } \\
\text { program has increased girls' }\end{array}$ & $\begin{array}{l}\text { Team's support for government } \\
\text { gender-focused pilot initiatives was } \\
\text { appreciated. }\end{array}$ & \\
\hline
\end{tabular}




\begin{tabular}{|c|c|c|c|}
\hline Country $^{1}$ & Coverage of Gender Issues & Engagement with the Authorities & Good Practices \\
\hline $\begin{array}{l}\text { WAEMU } \\
\text { (2016 Selected } \\
\underline{\text { Issues) }}\end{array}$ & $\begin{array}{l}\text { school enrollment; gender budgeting } \\
\text { includes e-wallet program to increase } \\
\text { access to agricultural inputs. Article IV } \\
\text { consultation analyzed gender } \\
\text { inequality. Female labor force } \\
\text { participation is very low in some of } \\
\text { the WAEMU countries. WAEMU } \\
\text { countries are outperformed by } \\
\text { benchmark countries in educational } \\
\text { equality between boys and girls as } \\
\text { well as in health indicators countries. }\end{array}$ & $\begin{array}{l}\text { Outreach activities by mission } \\
\text { chief/resident representatives were very } \\
\text { well received by official and public } \\
\text { audiences and press. }\end{array}$ & \\
\hline $\begin{array}{l}\text { Niger } \\
\text { (2016 Article IV } \\
\text { Staff Report and } \\
\text { Selected Issues) }\end{array}$ & $\begin{array}{l}\text { Macroeconomic consequences of } \\
\text { gender inequality. } \\
\text { The Fund-supported ECF-program } \\
\text { includes a structural benchmark for } \\
\text { the government to elaborate a new } \\
\text { national gender policy under } \\
\text { preparation by the authorities by } \\
\text { December } 2017 \text {. }\end{array}$ & $\begin{array}{l}\text { There has been interest and traction with } \\
\text { the authorities, as evidenced in the } \\
\text { agreement on the structural benchmark } \\
\text { under the program. }\end{array}$ & $\begin{array}{l}\text { Teams presented their work to } \\
\text { various stakeholders, including } \\
\text { CSOs. }\end{array}$ \\
\hline $\begin{array}{l}\text { Rwanda } \\
\text { (2017 Article IV } \\
\text { Staff Report and } \\
\text { Selected Issues) }\end{array}$ & $\begin{array}{l}\text { Examines the various initiatives } \\
\text { undertaken to close gender gaps over } \\
\text { the past decade, benchmarks } \\
\text { Rwanda's gender-related social- } \\
\text { economic outcomes compared to } \\
\text { other countries over time, analyzes } \\
\text { the impact of gender inequality on } \\
\text { growth and income inequality in the } \\
\text { country, and provides policy } \\
\text { recommendations. }\end{array}$ & $\begin{array}{l}\text { There has been interest and traction with } \\
\text { the authorities, as evidenced in the } \\
\text { appreciation of engagement on the } \\
\text { project. }\end{array}$ & \\
\hline
\end{tabular}




\begin{tabular}{|c|c|c|c|}
\hline \multicolumn{4}{|c|}{ Table 1. First- and Second-Wave Pilots (continued) } \\
\hline Country ${ }^{1}$ & Coverage of Gender Issues & Engagement with the Authorities & Good Practices \\
\hline APD & & & \\
\hline $\begin{array}{l}\text { India² } \\
\text { (First wave) } \\
\text { (2015 Article IV } \\
\text { Staff Report and } \\
\text { Selected Issues) } \\
\\
\text { India }{ }^{2} \\
\text { (2016 Article IV } \\
\text { Staff Report and } \\
\text { Selected Issues) }\end{array}$ & $\begin{array}{l}\text { In } 2015 \text {, staff analyzed determinants } \\
\text { of labor force participation using } \\
\text { household data and unemployment } \\
\text { surveys. The analysis showed urban- } \\
\text { rural disparities in female labor force } \\
\text { participation as well as a growing } \\
\text { gender gap in participation rates. } \\
\text { In } 2016 \text {, staff highlighted India's low } \\
\text { rates of female labor force } \\
\text { participation and that females receive } \\
\text { lower wages, are overrepresented in } \\
\text { informal and unpaid domestic work, } \\
\text { and gender gaps exist along several } \\
\text { other dimensions including education } \\
\text { and access to finance. A reduction in } \\
\text { these gender gaps leads to a positive } \\
\text { impact on real output and } \\
\text { employment. The Report, Selected } \\
\text { Issues Paper (SIPs), and working } \\
\text { papers show that investments in } \\
\text { infrastructure and social spending as } \\
\text { well as more flexible labor markets are } \\
\text { essential to boosting female labor } \\
\text { force participation. }\end{array}$ & $\begin{array}{l}\text { The team's presentation of their research } \\
\text { was well-received by the authorities. The } \\
\text { Managing Director's March } 2016 \text { visit to } \\
\text { India further brought this gender work } \\
\text { into the forefront and was widely } \\
\text { publicized by the Indian media. } \\
\text { The team's presentation of their research } \\
\text { was well-received by the authorities and } \\
\text { in line with the government's focus on } \\
\text { female empowerment and education. }\end{array}$ & $\begin{array}{l}\text { The team presented their work on } \\
\text { multiple platforms, which helped } \\
\text { gain strong traction and interest in } \\
\text { this kind of analysis. } \\
\text { The team presented twice in the } \\
\text { operationalizing gender group, } \\
\text { which led to some useful } \\
\text { discussions and recommendations. } \\
\text { Increasing the frequency of such } \\
\text { engagements would be helpful. }\end{array}$ \\
\hline $\begin{array}{l}\text { India }{ }^{2} \\
\text { (Second wave) } \\
\text { (2017 Article IV } \\
\text { Staff Report and } \\
\text { Selected Issues) } \\
\end{array}$ & $\begin{array}{l}\text { Consistent with the themes in the } \\
2015 \text { and } 2016 \text { Article IV reports, the } \\
2017 \text { Article IV report continued to } \\
\text { highlight India's large gender gaps in } \\
\text { the labor market, particularly low }\end{array}$ & $\begin{array}{l}\text { The team presented findings and related } \\
\text { policy implications at the Ministry of } \\
\text { Finance and the Reserve Bank of India, to } \\
\text { think-tanks, conferences and policy } \\
\text { workshops across India. }\end{array}$ & $\begin{array}{l}\text { Focused engagement with } \\
\text { concerned ministries and external } \\
\text { experts before, during and after } \\
\text { Article IV missions helped the team } \\
\text { gain traction with the authorities, }\end{array}$ \\
\hline
\end{tabular}




\begin{tabular}{|c|c|c|c|}
\hline \multicolumn{4}{|c|}{ Table 1. First- and Second-Wave Pilots (continued) } \\
\hline Country ${ }^{1}$ & Coverage of Gender Issues & Engagement with the Authorities & Good Practices \\
\hline & $\begin{array}{l}\text { female labor force participation, while } \\
\text { also turning more focus on India's } \\
\text { declining child sex ratios, the existing } \\
\text { gender gaps in business } \\
\text { opportunities, entrepreneurship, and } \\
\text { access to formal sources of finance. } \\
\text { Moreover, the team showed that } \\
\text { spending on rural infrastructure and } \\
\text { improving access to sanitation is } \\
\text { essential for achieving gender equality } \\
\text { and economic growth. }\end{array}$ & $\begin{array}{l}\text { Engagement with the authorities and } \\
\text { external experts in the field has been } \\
\text { positive, and they have been receptive to } \\
\text { Fund work and policy advice. }\end{array}$ & $\begin{array}{l}\text { share knowledge and explore } \\
\text { synergies. }\end{array}$ \\
\hline $\begin{array}{l}\text { Japan } \\
\text { (2017 Article IV } \\
\text { Staff Report) }\end{array}$ & $\begin{array}{l}\text { Examines the impact of labor market } \\
\text { reform, including increase in female } \\
\text { labor market participation to achieve } \\
\text { gender equality, such as ensuring } \\
\text { equal-pay for equal-work, and } \\
\text { supporting investments in health and } \\
\text { childcare. In addition, the analytical } \\
\text { work would examine factors } \\
\text { underlying labor market outcomes for } \\
\text { women in Japan. }\end{array}$ & $\begin{array}{l}\text { The authorities are supportive of the } \\
\text { work given initiatives on labor market } \\
\text { reform. The government's policy agenda } \\
\text { includes decision to double the spousal } \\
\text { tax deduction as part of the } 2017 \\
\text { budget, and increase budgetary } \\
\text { resources for child-care facilities. } \\
\text { Current discussions with respect to work } \\
\text { style reform (telework, labor contracts, } \\
\text { limiting overtime hours) are broadly in } \\
\text { line with IMF recommendations. }\end{array}$ & $\begin{array}{l}\text { The team benefited from a clear } \\
\text { recognition by the authorities of the } \\
\text { importance of macro-structural } \\
\text { reforms as part of economic revival } \\
\text { based on structural reform as the } \\
\text { third "arrow" of Abenomics. }\end{array}$ \\
\hline \multicolumn{4}{|c|}{ ( } \\
\hline $\begin{array}{l}\text { Austria } \\
\text { (2016 Article IV } \\
\text { Staff Report) }\end{array}$ & $\begin{array}{l}\text { Impact of female labor force } \\
\text { participation on growth. }\end{array}$ & $\begin{array}{l}\text { The Ministry of Labor was interested in } \\
\text { the work, given plans to expand } \\
\text { childcare provision in order to } \\
\text { strengthen education and allow parents } \\
\text { to work full time. }\end{array}$ & $\begin{array}{l}\text { Useful discussion on a matter } \\
\text { important for both raising economic } \\
\text { growth and alleviating pressures on } \\
\text { the pension system. }\end{array}$ \\
\hline \multicolumn{4}{|c|}{ 'The table provides hyperlinks to first- and second-wave pilots' Article IV staff reports, Selected Issues, and working papers. } \\
\hline
\end{tabular}




\begin{tabular}{|c|c|c|c|}
\hline Country $^{1}$ & Coverage of Gender Issues & Engagement with the Authorities & Good Practices \\
\hline $\begin{array}{l}\text { Germany } \\
\begin{array}{l}(2015 \text { Article IV } \\
\text { staff report and } \\
\text { Selected Issues) }\end{array}\end{array}$ & $\begin{array}{l}\text { Empirical work on factors affecting } \\
\text { female labor force participation in the } \\
\text { Western Balkan countries where } \\
\text { gender gap in labor force } \\
\text { participation has been persistently } \\
\text { higher than in EU countries. On } \\
\text { average, about } 70 \text { percent of women } \\
\text { in Western Balkan region are either } \\
\text { outside the labor force or are } \\
\text { unemployed. The study will use both } \\
\text { macro- and micro- level data for its } \\
\text { analysis. } \\
2015 \text { Article IV discusses importance } \\
\text { of stronger policies to spur female } \\
\text { labor force participation to counter } \\
\text { adverse effects of population aging } \\
\text { on labor supply. While female labor } \\
\text { force participation is one of the } \\
\text { highest in advanced economies, about } \\
\text { half of women work part-time. Policies } \\
\text { should be aimed at reducing existing } \\
\text { disincentives for women to work full- } \\
\text { time to ensure future growth. }\end{array}$ & $\begin{array}{l}\text { The mission had a productive discussion } \\
\text { with the Minister of Labor and her team. } \\
\text { The ministry views a lack of adequate } \\
\text { and affordable childcare as the main } \\
\text { obstacle behind low female labor force } \\
\text { participation in Macedonia. With fiscal } \\
\text { constraints and a sizable pool of low- } \\
\text { earners, the authorities plan to introduce } \\
\text { double shifts in childcare facilities and } \\
\text { income-testing for childcare payment. As } \\
\text { a first step, the authorities have collected } \\
\text { detailed data on childcare facilities and } \\
\text { users at the municipality level. } \\
\text { Gender issues were addressed in the } \\
\text { context of potential } \\
\text { growth/demographics and entered in a } \\
\text { relatively seamless way. }\end{array}$ & $\begin{array}{l}\text { Preparing a cross-country working } \\
\text { paper on low female participation } \\
\text { and employment issues created } \\
\text { synergies, as these challenges are } \\
\text { endemic to several countries in the } \\
\text { Western Balkan region. The existing } \\
\text { literature and work done by others } \\
\text { in the Fund provided informative } \\
\text { guidance. }\end{array}$ \\
\hline $\begin{array}{l}\text { Hungary } \\
\text { (2015 Article IV } \\
\text { Staff Report and } \\
\text { Selected Issues) }\end{array}$ & $\begin{array}{l}\text { Staff advocated a 3-pronged } \\
\text { approach to increase female labor } \\
\text { force participation: income support } \\
\text { and/or tax incentives, family-friendly } \\
\text { work conditions, and affordable child- } \\
\text { care. }\end{array}$ & $\begin{array}{l}\text { Not much interest from authorities } \\
\text { during discussions, but analysis may } \\
\text { have encouraged them to think about } \\
\text { this issue. }\end{array}$ & $\begin{array}{l}\text { informative. } \\
\text { 4) Buy-in from some country } \\
\text { authorities was an issue. } \\
\text { 5) Resource constraints arose, given } \\
\text { all other work priorities. }\end{array}$ \\
\hline
\end{tabular}


Table 1. First- and Second-Wave Pilots (continued)

\begin{tabular}{|c|c|c|c|}
\hline Country ${ }^{1}$ & Coverage of Gender Issues & Engagement with the Authorities & Good Practices \\
\hline $\begin{array}{l}\text { Iceland } \\
\text { (Sixth Post- } \\
\text { Program } \\
\text { Monitoring, } \\
2015)\end{array}$ & $\begin{array}{l}\text { Authorities are conducting a major } \\
\text { overhaul of budgetary practices with } \\
\text { legislation that explicitly establishes } \\
\text { gender budgeting (GB) and incorporates } \\
\text { gender equality perspective at all levels } \\
\text { of budgetary process. In TA and } \\
\text { surveillance, staff wanted to highlight } \\
\text { initiative and offer constructive } \\
\text { suggestions. Over several missions, staff } \\
\text { regularly met with GB committee and } \\
\text { Ministry of Finance staff. }\end{array}$ & $\begin{array}{l}\text { Significant interest within the Ministry of } \\
\text { Finance for the IMF contribution on } \\
\text { gender budgeting. Moreover, Ministry of } \\
\text { Finance staff appreciated that IMF staff } \\
\text { took the topic seriously. }\end{array}$ & \\
\hline $\begin{array}{l}\text { Italy } \\
\text { (2016 Article IV } \\
\text { Staff Report and } \\
\text { Selected Issues) } \\
\end{array}$ & $\begin{array}{l}\text { Low female labor force participation } \\
\text { in Italy is not necessarily the result of } \\
\text { unconstrained choice. Insights from } \\
\text { existing studies and evidence from } \\
\text { Italian provinces suggest a substantial } \\
\text { role for policies, such as removing } \\
\text { fiscal disincentives and enhancing the } \\
\text { supply of child- and elderly-care } \\
\text { services to support women's decisions } \\
\text { to enter the labor market. }\end{array}$ & & \\
\hline $\begin{array}{l}\text { Poland } \\
\text { (2016 Article IV } \\
\text { Staff Report and } \\
\text { Selected Issues) }\end{array}$ & $\begin{array}{l}\text { Analytical work on female labor force } \\
\text { participation. }\end{array}$ & $\begin{array}{l}\text { The team presented the paper at a } \\
\text { seminar at the Ministry of Finance. }\end{array}$ & $\begin{array}{l}\text { The use of existing cross-country } \\
\text { research on drivers of female labor } \\
\text { force participation combined with } \\
\text { country-specific tailoring of the } \\
\text { assessment enriched the team's } \\
\text { analysis and policy advice. }\end{array}$ \\
\hline $\begin{array}{l}\text { Sweden } \\
\text { (Working Paper) }\end{array}$ & $\begin{array}{l}\text { Christiansen and others (2016) } \\
\text { examine link between gender diversity } \\
\text { in senior corporate positions and }\end{array}$ & $\begin{array}{l}\text { WP presentation at Ministry of Finance } \\
\text { had high turnout, well received; team did } \\
\text { not address gender issues in Article IV }\end{array}$ & \\
\hline
\end{tabular}




\begin{tabular}{|c|c|c|c|}
\hline Country ${ }^{1}$ & Coverage of Gender Issues & Enqagement with the Authorities & Good Practices \\
\hline & $\begin{array}{l}\text { financial performance; document } \\
\text { positive association between } \\
\text { corporate return on assets and the } \\
\text { share of women in senior positions. }\end{array}$ & $\begin{array}{l}\text { discussions as it was not known at time } \\
\text { of mission that Sweden was a pilot. }\end{array}$ & \\
\hline \multicolumn{4}{|c|}{ e } \\
\hline $\begin{array}{l}\text { Egypt } \\
\text { (Request for } \\
\text { Extended Fund } \\
\text { Facility, 2017) }\end{array}$ & $\begin{array}{l}\text { Analysis of challenges to job creation } \\
\text { and female labor participation. } \\
\text { The EFF program includes structural } \\
\text { conditionality aimed at supporting } \\
\text { female labor participation. }\end{array}$ & $\begin{array}{l}\text { The SIP on inclusive growth presented at } \\
\text { the time of upcoming } 2017 \text { Article IV } \\
\text { consultation and second review under the } \\
\text { program includes a diagnostic and policy } \\
\text { recommendations on the specific } \\
\text { constraints facing women in the labor } \\
\text { market. }\end{array}$ & $\begin{array}{l}\text { Collaboration with other institutions } \\
\text { works well to create expertise and } \\
\text { elaborate a diagnosis. }\end{array}$ \\
\hline $\begin{array}{l}\text { Iran } \\
\text { (2016 Article IV } \\
\text { Staff Report and } \\
\text { Selected Issues, } \\
\text { 2017/18 Article } \\
\text { IV Staff Report } \\
\text { and Selected } \\
\text { Issues) }\end{array}$ & $\begin{array}{l}\text { Impact of female labor force } \\
\text { participation on growth and policy } \\
\text { recommendations. } \\
\text { SIP focused on job creation and } \\
\text { presented labor data by gender. }\end{array}$ & $\begin{array}{l}\text { The SIP was presented to the authorities } \\
\text { (CB and MOF). Team engaged with Vice } \\
\text { President for Women and Family Affairs } \\
\text { and female entrepreneurs. Team } \\
\text { discussed recommendations in } \\
\text { concluding meeting: the authorities were } \\
\text { engaged and took note of advice. They } \\
\text { pointed out that the official data } \\
\text { unreported female labor force } \\
\text { participation due to social and cultural } \\
\text { norms. }\end{array}$ & $\begin{array}{l}\text { Support of ED and counterparts was } \\
\text { key in securing meetings: early } \\
\text { engagement was key to explain and } \\
\text { motivate the work. Openness to } \\
\text { engage, and have counterparts join } \\
\text { meetings-- facilitated interactions } \\
\text { and connections across parts of the } \\
\text { government. Reaching out to WB } \\
\text { and other contacts to identify } \\
\text { whom to meet. }\end{array}$ \\
\hline $\begin{array}{l}\text { Morocco } \\
\text { (2016 Article IV } \\
\text { Staff Report and } \\
\text { Selected Issues) }\end{array}$ & $\begin{array}{l}\text { Impact of gender inequality on } \\
\text { growth, compared to groups of faster } \\
\text { growing countries and estimates of } \\
\text { income losses due to low female labor } \\
\text { force participation. Policy } \\
\text { recommendations: to promote gender }\end{array}$ & $\begin{array}{l}\text { Mixed. While main official counterparts } \\
\text { (MOF and CB) agreed with the main } \\
\text { results of the paper, they pointed to } \\
\text { social, cultural and religious norms as } \\
\text { main drivers of gender inequality. On the } \\
\text { other hand, there was more traction with }\end{array}$ & $\begin{array}{l}\text { Fact-based and well-researched } \\
\text { gender-piece may have played a } \\
\text { role in convincing the authorities } \\
\text { that gender inequality needed to be } \\
\text { tackled. That said, some resistance } \\
\text { due to social and cultural norms }\end{array}$ \\
\hline
\end{tabular}




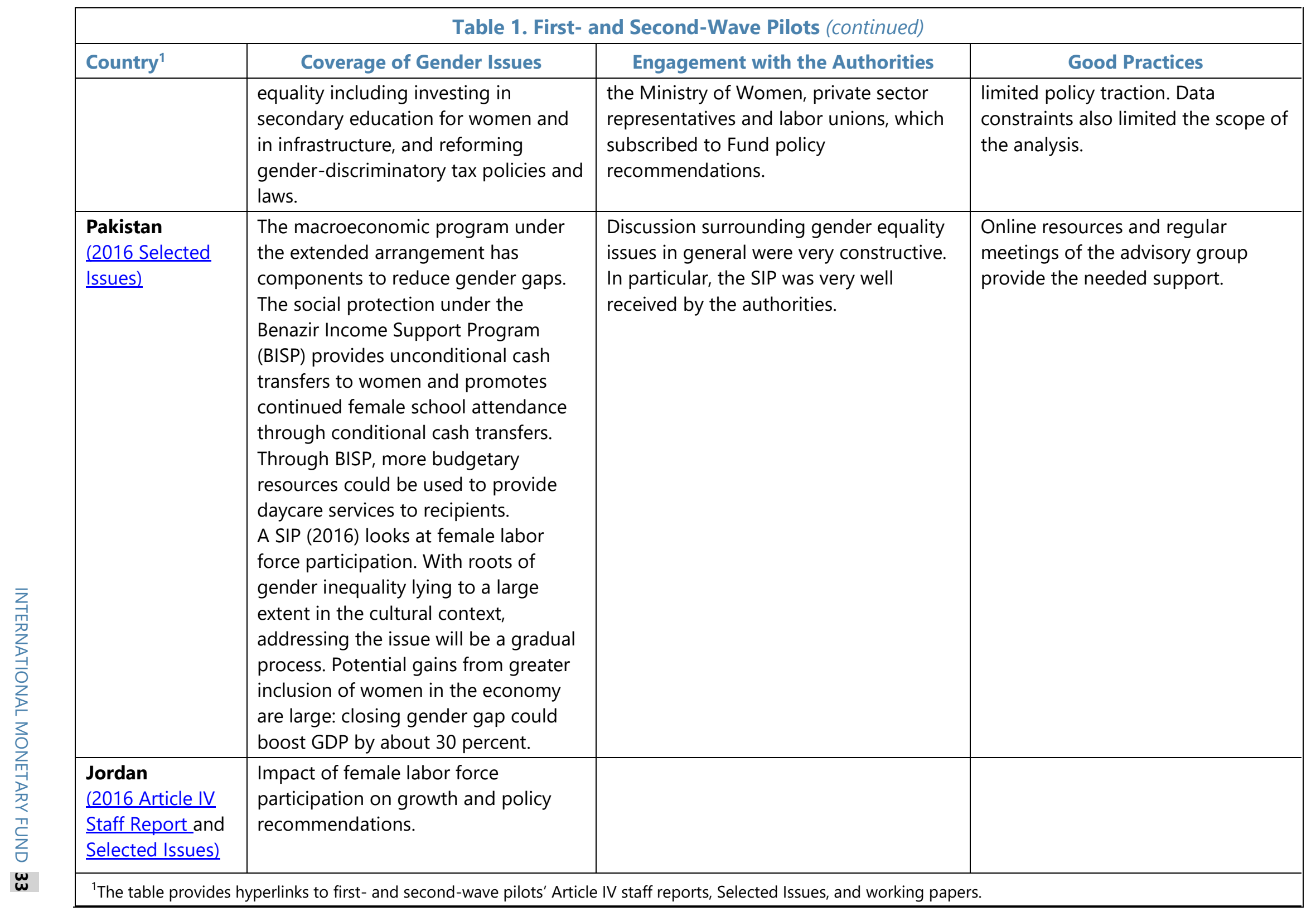




\begin{tabular}{|c|c|c|c|}
\hline & & & \\
\hline & & $\begin{array}{l}\text { The Ministry of Labor will finalize the } \\
\text { revisions to the } 2011 \text { National } \\
\text { Employment Strategy (NES) based on the } \\
\text { recommendations of the recent review } \\
\text { conducted with the ILO and align it with } \\
\text { the National Strategy for Human } \\
\text { Resources Development (NSHRD) by } \\
\text { mid-2017. }\end{array}$ & $\begin{array}{l}\text { The team met with ITUCs and CSOs, } \\
\text { and hosted a breakfast with leading } \\
\text { women. }\end{array}$ \\
\hline \multicolumn{4}{|l|}{ WHD } \\
\hline $\begin{array}{l}\text { Canada } \\
\text { (2017 Working } \\
\text { Paper) }\end{array}$ & $\begin{array}{l}\text { Impact of female labor force } \\
\text { participation on labor productivity } \\
\text { growth. Findings suggest that if the } \\
\text { current gap of } 7 \text { percentage points } \\
\text { between male and female labor force } \\
\text { participation with post-secondary } \\
\text { education were eliminated, the level } \\
\text { of real GDP could be about } \\
4 \text { percentage points higher today. }\end{array}$ & $\begin{array}{l}\text { Discussed preliminary findings with } \\
\text { Canadian academia and government } \\
\text { officials. Both parties are interested. }\end{array}$ & $\begin{array}{l}\text { Support from Management was } \\
\text { instrumental for visibility of the } \\
\text { work (MD posted a blog on } \\
\text { Canada's gender issues based on } \\
\text { the research findings). }\end{array}$ \\
\hline $\begin{array}{l}\text { Chile } \\
\text { (2015 Article IV } \\
\text { Staff Report) }\end{array}$ & $\begin{array}{l}\text { Very low levels of female labor force } \\
\text { participation and formal employment. } \\
\text { The quality of jobs is also relatively } \\
\text { poorer, with } 85 \text { percent of women } \\
\text { working in service sector, mostly on } \\
\text { low-skilled activities. Staff highlighted } \\
\text { need to extend early childhood } \\
\text { education and childcare services, } \\
\text { remove mandated employer provided } \\
\text { childcare, and invest in transport } \\
\text { infrastructure. }\end{array}$ & & \\
\hline
\end{tabular}




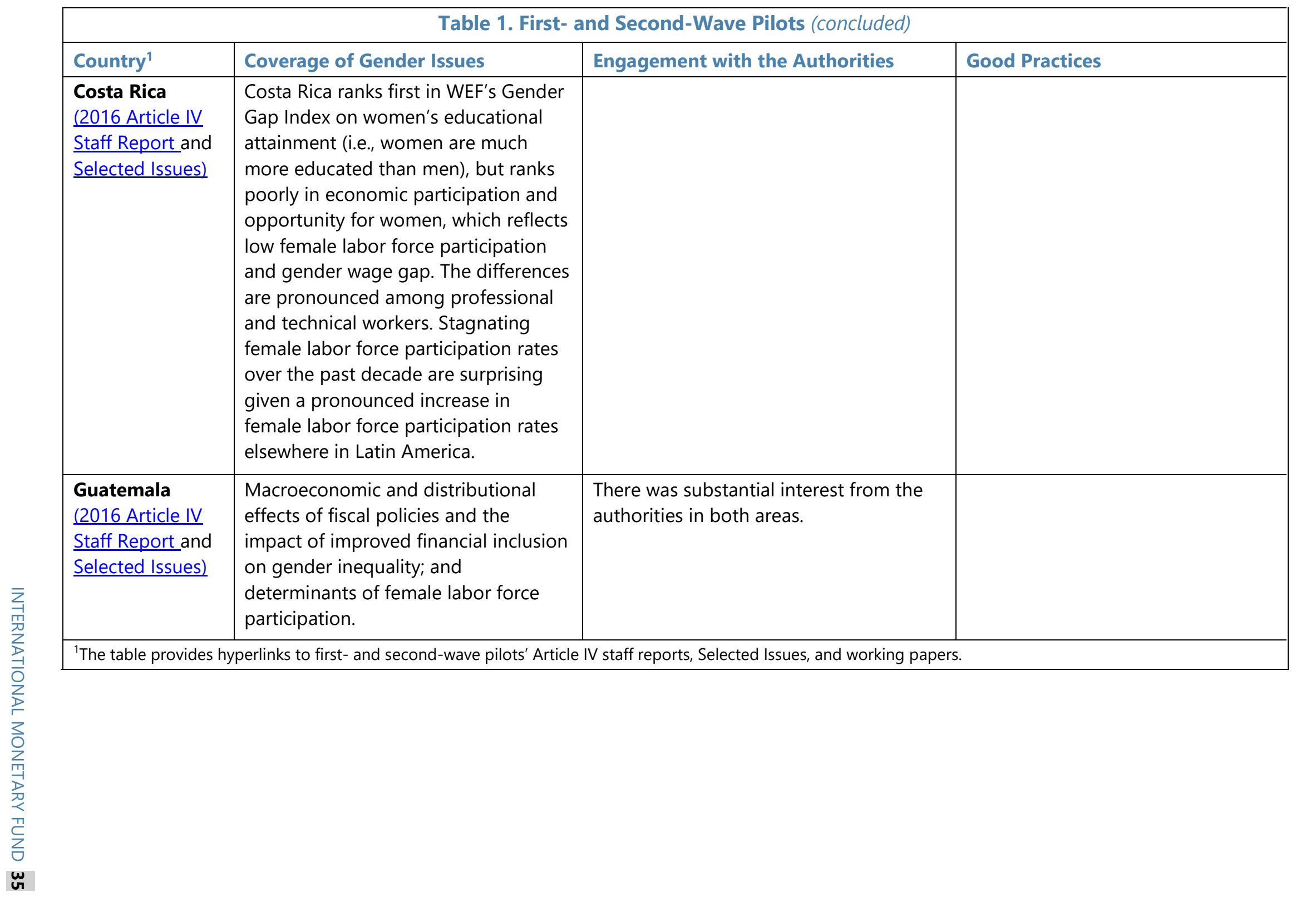




\begin{tabular}{|c|c|}
\hline \multicolumn{2}{|r|}{ Table 2. Third-Wave Pilots } \\
\hline Department & Country \\
\hline AFR & $\begin{array}{l}\text { Cameroon }^{1} \\
\text { Nigeria }^{2} \\
\text { Senegal }^{1} \\
\text { Tanzania }^{1}\end{array}$ \\
\hline APD & $\begin{array}{l}\text { Australia }^{2} \\
\text { Lao P.D.R. } \\
\text { Mongolia }{ }^{1,2}\left(1^{\text {st }} \text { and } 2^{\text {nd }} \text { Reviews under the EFF }\right)\end{array}$ \\
\hline EUR & $\begin{array}{l}\text { Czech Republic } \\
\text { Israel }^{2} \\
\text { Norway }^{2} \text { (2017 Article IV and Selected Issues) } \\
\text { Serbia }\end{array}$ \\
\hline MCD & $\begin{array}{l}\text { Iran }^{2} \\
\text { Kyrgyz Republic }{ }^{1,2}\left(4^{\text {th }} \text { and } 5^{\text {th }} \text { Reviews under the ECF) }\right.\end{array}$ \\
\hline WHD & $\begin{array}{l}\text { Argentina }^{2} \text { (2017 Article IV and Selected Issues) } \\
\text { Jamaica } 1,2\end{array}$ \\
\hline \multicolumn{2}{|c|}{$\begin{array}{l}{ }^{1} \text { Six out of the } 15 \text { countries participating in the third-wave pilots have a Fund-supported program. These are Cameroon } \\
\text { and Kyrgyz Republic (Extended Credit Facility (ECF)), Senegal and Tanzania (Policy Support Instrument (PSI)), Mongolia } \\
\text { (Extended Fund Facility (EFF)), and Jamaica (Precautionary Standby Arrangement (SBA)). } \\
\text { 2Pilot has been completed. }\end{array}$} \\
\hline
\end{tabular}

\section{CInternational Monetary Fund. Not for Redistribution}




\section{References}

Aguirre, D., L. Hoteit, C. Rupp, and K. Sabbagh, 2012, "Empowering the Third Billion. Women and the World of Work in 2012," Booz and Company.

Aslan, G., C. Deléchat, M. Newiak, and F. Yang, 2017, "Inequality in Financial Inclusion and Income Inequality," IMF Working Paper, WP/17/236 (Washington: International Monetary Fund).

Atoyan, R. and J. Rahman, 2017, "Western Balkans: Increasing Women's Role in the Economy." IMF Working Paper, WP/17/195 (Washington: International Monetary Fund).

Bloom, D. E., D. Canning, G. Fink, and J. E. Finlay, 2009, "Fertility, Female Labor Force Participation, and the Demographic Dividend," Journal of Economic Growth Vol. 14, pp. 79-101.

Christiansen, L., H. Lin, J. Pereira, P. Topalova, and R. Turk, 2016a, "Individual Choice or Policies? Drivers of Female Employment in Europe," IMF Working Paper, WP/16/49 (Washington: International Monetary Fund).

,2016b, "Gender Diversity in Senior Positions and Firm Performance: Evidence from Europe," IMF Working Paper, WP/16/50. (Washington: International Monetary Fund).

,2016c, "Unlocking Female Employment Potential in Europe. Drivers and Benefits," IMF Departmental Paper (European Department and Strategy, Policy, and Review Department), (Washington: International Monetary Fund).

Clements, B., and J. Stotsky, 2017, "Tax and Spending Policies to Achieve Greater Gender Equality," In: Women, Work, and Economic Growth. Leveling the Playing Field.

Cuberes, D. and M. Teignier, 2014, "Aggregate Costs of Gender Gaps in the Labor Market: A Quantitative Estimate," UB Economics Working Papers No. E14/308 Universitat de Barcelona.

2016, "Aggregate Effects of Gender Gaps in the Labor Market: A Quantitative Estimate," Journal of Human Capital Vol. 10, No 1, pp. 1-32.

Das, S., S. Jain-Chandra, K. Kochhar, and N. Kumar, 2015, "Women Workers in India: Why So Few Among So Many?" IMF Working Paper WP/15/55 (Washington: International Monetary Fund).

Duflo, E. 2003, "Grandmothers and Granddaughters: Old-Age Pensions and Intrahousehold Allocation in South Africa," World Bank Economic Review Vol. 17. No. 1, pp. 1-25.

,2012, "Women Empowerment and Economic Development," Journal of Economic

Literature Vol. 50, No. 4, pp. 1051-1079.

Elborgh-Woytek, K., M. Newiak, K. Kochhar, S. Fabrizio, K. Kpodar, P. Wingender, B. Clements, and G. Schwartz, 2013, "Women, Work, and the Economy: Macroeconomic Gains from Gender Equity." IMF Staff Discussion Note SDN/13/10. (Washington: International Monetary Fund). 
Esteve-Volart, B., 2004, "Gender Discrimination and Growth: Theory and Evidence from India," s.l.: LSE STICERD Research Paper No. DEDPS 42, 2004.

Gonzales, C., S. Jain-Chandra, K. Kochhar, M. Newiak, and T. Zeinullayev, 2015a, "Catalyst for Change: Empowering Women and Tackling Income Inequality," IMF Staff Discussion Note SDN/15/20 (Washington: International Monetary Fund).

2015b, "Fair Play: More Equal Laws Boost Female Labor Force Participation," IMF Staff Discussion Note SDN/15/02 (Washington: International Monetary Fund).

Hammer, C., D. Kostroch, G. Quirós, and STA Internal Group, 2017, "Big Data: Potential, Challenges, and Statistical Implications," IMF Staff Discussion Note SDN/17/06, September (Washington: International Monetary Fund).

Holloway, K., Z. Niazi, and R. Rouse, 2017, "Women's Economic Empowerment Through Financial Inclusion. A Review of Existing Evidence and Remaining Knowledge Gaps, "Innovation for Poverty Action, March.

International Monetary Fund, 2013a, "Jobs and Growth: Analytical and Operational Considerations for the Fund," IMF Board Paper, March (Washington).

,2013b, "Guidance Note on Jobs and Growth Issues in Surveillance and Program Work," IMF Policy Document, (Washington).

,2013c, Regional Economic Outlook, Middle East and Central Asia, November, (Washington).

,2014, "2014 Triennial Surveillance Review," (Washington).

„2015a, "Guidance Note for Surveillance under Article IV Consultations," (Washington).

2015b, Regional Economic Outlook, Sub-Saharan Africa, Dealing with the Gathering Clouds, October (Washington).

,2017a, Fiscal Monitor: Tackling Inequality, October (Washington).

,2017b, "Gender Budgeting in G7 Countries," IMF Staff Paper, April (Washington).

Kazandjian, R., L. Kolovich, K. Kochhar, and M. Newiak, 2016, "Gender Equality and Economic Diversification," IMF Working Paper 16/140, (Washington: International Monetary Fund).

Khera, P. 2016, "Macroeconomic Impacts of Gender Inequality and Informality in India," IMF Working Paper 16/16, (Washington: International Monetary Fund). 
Klasen, S. 1999, "Does Gender Inequality Reduce Growth and Development? Evidence from Cross-Country Regressions," World Bank Policy Research Report Background Paper No.7. (Washington: International Monetary Fund).

and F. Lamanna, 2009, "The Impact of Gender Inequality in Education and Employment on Economic Growth: New Evidence for a Panel of Countries," Feminist Economics. Vol. 15:3, pp. 91-132.

Kochhar, K., S. Jain-Chandra, and M. Newiak, 2017, Women, Work, and Economic Growth: Leveling the Playing Field. (Washington: International Monetary Fund).

Kolovich, L., V. Malta, and M. Mendes Tavares. 2017. "Addressing Gender Issues in Argentina's Labor Market." Chapter IV. Selected Issues. IMF Country Report No. 17/410. (Washington: International Monetary Fund).

Loko, B. and M. Diouf, 2009, "Revisiting the Determinants of Productivity Growth: What's New?" IMF Working Paper 09/225. (Washington: International Monetary Fund).

Miller, G. 2008, "Women's Suffrage, Political Responsiveness, and Child Survival in American History." Quarterly Journal of Economics. August, pp. 1287-1326.

Novta, N. and J. C. Wong, 2017, "Women at Work in Latin America and the Caribbean," IMF Working Paper 17/34. (Washington: International Monetary Fund).

Ostry, J., A. Berg, and C. Tsangarides, 2014, "Redistribution, Inequality, and Growth," IMF Staff Discussion Note 14/02. (Washington: International Monetary Fund).

Rubalcava, L., G. Teruel, and D. Thomas, 2004, "Spending, Saving and Public Transfers to Women," California Center of Population Research UCLA, On-Line Working Paper Series, CCPR-024-04.

Sahay, R., M. Cihak, P. N'Diaye, A. Barajas, A. Kyobe, S. Mitra, Y. Mooi, and S. Yousefi, 2017, “Banking on Women Leaders: A Case for More?" IMF Working Paper WP/17/199. (Washington: International Monetary Fund).

Steinberg, C. and M. Nakane, 2012, "Can Women Save Japan?" IMF Working Paper 12/48. (Washington: International Monetary Fund).

Tertilt, M. 2005, "Polygyny, Fertility, and Savings," Journal of Political Economy. Vol 113, No. 6.

Thomas, D. 1990, "Intra-Household Resource Allocation. An Inferential Approach," The Journal of Human Resources. Vol. 25, No. 4, pp. 635-64.

World Economic Forum, 2014, "Global Gender Gap Report 2014," (Cologny: WEF).

World Bank, 2012, "World Development Report: Gender Equality and Development," (Washington: World Bank Group). 2015, "Women, Business and the Law 2016: Getting to Equal," (Washington: World Bank Group). 